\title{
Types, characteristics and anatomic location of physical signs in elder abuse: a systematic review
}

\section{Awareness and recognition of injury patterns}

\author{
Miriam E. van Houten ${ }^{1,2,3}$ (1) $\cdot$ Lilian C. M. Vloet ${ }^{2,4} \cdot$ Thomas Pelgrim $^{5} \cdot$ Udo J. L. Reijnders ${ }^{6} \cdot$ Sivera A. A. Berben $^{2,4}$
}

Received: 18 April 2021 / Accepted: 28 July 2021 / Published online: 13 September 2021

(c) The Author(s) 2021

\section{Key summary points}

Aim Identify types, characteristics and anatomic location of physical signs in elder abuse.

Findings Physical signs in elder abuse are most common bruises and anatomically predominantly located on the head, face/ maxillofacial area, neck, upper extremities and torso.

Message Increase knowledge on physical signs in elder abuse so as to enhance timely detection and intervention.

\begin{abstract}
Purpose Elder abuse is a worldwide problem with serious consequences for individuals and society. The recognition of elder abuse is complex due to a lack of awareness and knowledge. In this systematic review, types, characteristics and anatomic location of physical signs in elder abuse were identified.

Methods Databases of MEDLINE, COCHRANE, EMBASE and CINAHL were searched. The publication dates ranged from March 2005 to July 2020. In addition to the electronic searches, the reference lists and citing of included articles were hand-searched to identify additional relevant studies. The quality of descriptive and mixed-methods studies was assessed.

Results The most commonly described physical signs in elder abuse were bruises. The characteristics of physical signs can be categorized into size, shape and distribution. Physical signs were anatomically predominantly located on the head, face/ maxillofacial area (including eyes, ears and dental area), neck, upper extremities and torso (especially posterior). Physical signs related to sexual elder abuse were mostly located in the genital and perianal area and often accompanied by a significant amount of injury to non-genital parts of the body, especially the area of the head, arms and medial aspect of the thigh. Conclusions Most common types, characteristics and anatomic location of physical signs in elder abuse were identified. To enhance (early) detection of physical signs in elder abuse, it is necessary to invest in (more) in-depth education and to include expertise from a forensic physician or forensic nurse in multidisciplinary team consultations.
\end{abstract}

Keywords Bruises $\cdot$ Physical signs $\cdot$ Elder abuse $\cdot$ Distribution $\cdot$ Forensics

Miriam E. van Houten

Miriam.vanhouten@radboudumc.nl

Sivera A. A. Berben

Sivera.Berben@han.nl

1 Department of Geriatrics, Radboud University Medical Centre, PO Box 9101, 6500 HB Nijmegen, The Netherlands

2 Research Department of Emergency and Critical Care, Knowledge Centre of Sustainable Healthcare, School of Health Studies, HAN University of Applied Sciences, PO Box 6960, 6503 GL Nijmegen, The Netherlands
3 Trompetter and Partners Social Medical Expertise, Utrechtseweg 75, 3702 AA Zeist, The Netherlands

4 Radboud Institute for Health Sciences IQ Healthcare, Radboud University Medical Centre, P.O. Box 9101, 6500 HB Nijmegen, The Netherlands

5 School of Health Studies, Knowledge Centre of Sustainable Healthcare, HAN University of Applied Sciences, PO Box 6960, 6503 GL Nijmegen, The Netherlands

6 Department of Forensic Medicine, Amsterdam Public Health Service, PO Box 2200, 1000 CE Amsterdam, The Netherlands 


\section{Background}

Elder abuse is a worldwide problem with serious consequences for individuals and society, due to increased morbidity, mortality and use of healthcare resources, especially emergency services [1-3]. The definition of elder abuse is formulated by the World Health Organization (2017) as "a single or repeated act, or lack of appropriate action, occurring within any relationship where there is an expectation of trust, which causes harm or distress to an older person". There are various forms of elder abuse: financial, physical, psychological and sexual abuse. Elder abuse can also be the result of intentional or unintentional neglect. Based on available evidence it is estimated that $15.7 \%$ of people of 60 years and older worldwide are subjected to abuse [4]. This prevalence rate is likely to be an underestimate, as many cases of elder abuse are not reported. Furthermore, studies on prevalence rates in elder abuse often show heterogeneity due to regional and cultural differences between countries or varying definitions of elder abuse (for example with regard to age cutoff point) used. In the Netherlands, 1 in 20 people aged 65 years and over living at home experience elder abuse at some point in their lives, and 1 in 50 people aged 65 years and over living at home experience elder abuse on an annual basis [5].

There is complexity in the recognition of elder abuse. The level of awareness and knowledge on elder abuse in healthcare professionals is still poor and there is a strong need for education and specific training on recognition $[6,7]$. On the other hand, older persons will not always report circumstances of abuse because of cognitive and/or speech impairment [8]. But even if they are able, they will not always report being a victim of elder abuse because of fear from repercussions from the abuser, issues of shame or loyalty $[8,9]$. Interactions with healthcare professionals, such as physicians and nurses in the hospital setting, present crucial opportunities to recognize elder abuse and to intervene or to refer to the appropriate authorities [8]. Also signs of elder abuse are often detected in acute situations such as admittance to the ED (emergency department). Professionals in the ED may be the first healthcare professionals to have contact with the older persons. A study from Dong et al. [10] showed that older persons who experienced two or more types of elder abuse also had significantly higher rates of ED use. Also, they were less likely to hide signs of elder abuse in acute situations such as admittance to the ED.

Different types of elder abuse, such as physical abuse, sexual abuse and neglect, can cause physical injuries. The detection and recognition of physical signs related to elder abuse may be complicated because it is not always easy to discriminate from signs of underlying diseases. For example, age-related changes or certain medication can make the skin more vulnerable to injury, which makes it difficult to assess whether skin bruising is either of an accidental or of a nonaccidental nature. Furthermore, there are no known pathognomonic physical signs of elder abuse described, unlike in certain cases of child abuse [11-13].

In this systematic review, we aimed to identify the types (e.g., bruises), characteristics (e.g., size, shape and distribution) and anatomic location of physical signs in elder abuse to increase the awareness and recognition on injury (patterns) by clinical geriatricians and other healthcare professionals.

\section{Methods}

\section{Design}

A systematic review of the literature was performed according to the steps of the Cochrane Handbook for Systematic Reviews of Interventions [14], and reported in concordance with the Preferred Reporting Items for Systematic reviews and Meta-Analyses (PRISMA) statement [15].

\section{Search strategy}

The databases of MEDLINE, COCHRANE, EMBASE and CINAHL were searched. The publication dates ranged from March 2005 to July 2020. In addition to the electronic searches, the reference lists and citing of included articles were hand-searched to identify additional relevant studies. The search strategy was partly based on available MeSH terms from the search strategy protocol of the Cochrane review on Interventions for preventing abuse in the elderly [16]. Furthermore the (modified) search strategy protocol from the chapter on the recognition of physical signs related to elder abuse from the Dutch guideline on suspected elder abuse (NVKG 2018) was used [17]. The full search strategy per database is provided in Supplementary Information Text 1.

\section{Study selection procedure}

All types of reviews, quantitative and qualitative study designs were included, with the limitation of studies published in the Dutch, German, French and English language. The inclusion criteria were: studies containing a description of types of physical signs (related to elder abuse) with regard to their characteristics and/or anatomic location of physical signs. Excluded were: conference proceedings, editorials, or other personal communications and studies that focused on the prevalence of elder abuse, or legislation and education in elder abuse not related to physical injuries. Furthermore, studies on suicide, homicide, histological examination, use 
of restraints from a professional perspective or self-neglect of older persons were excluded. All articles were screened on title and abstract by two independent reviewers (SB, $\mathrm{MVH}$ ). In case of doubt, a third reviewer (LV) was asked to make a final decision. In addition, reference lists and citing of included articles were screened (SB, MVH) and potentially relevant new publications were screened in a similar way (see Fig. 1 for study selection process).

\section{Quality assessment}

To assess the quality of the descriptive studies, we used the 14-criteria quantitative tool from Kmet et al. [18]. We deleted three criteria from the tool (criteria five, six, and seven) regarding experimental research. The quality assessment was performed by two independent researchers (SB, MVH). To assess the quality of the mixed methods studies, a multimethod validated appraisal tool (MMAT version 2018) was used [19]. The MMAT is the only tool that includes specific criteria for mixed methods studies. With its five different sets of criteria, the MMAT uses a combination of individual component and mixed methods approaches. Any disagreements in criteria ratings between reviewers were discussed until a consensus was reached. No quality assessment was performed for the narrative reviews and case report studies. Instruments for the quality assessment of narrative reviews have been developed, but were not used in this systematic review because the results of narrative reviews were mostly based on the primary studies that were already included in this systematic review. The case report studies were mainly descriptions of individual patients where a quality assessment was not deemed to be of added value.

\section{Data extraction}

Data were extracted by two independent researchers (SB, MVH). Outcomes extracted were:

1. Types of physical signs in elder abuse.

2. Characteristics of physical signs in elder abuse.

3. Anatomic location of physical signs in elder abuse.

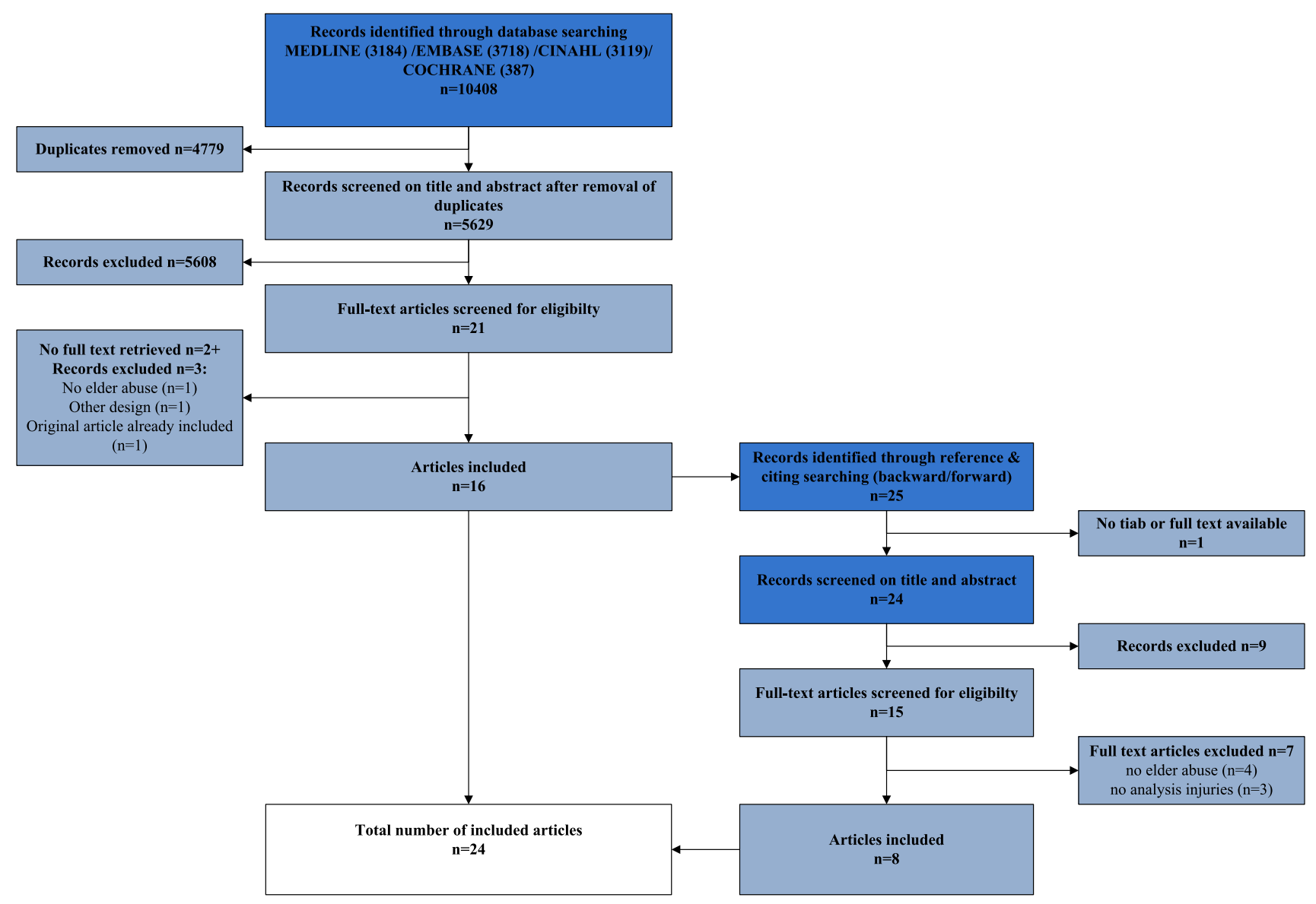

Fig. 1 Study selection process 


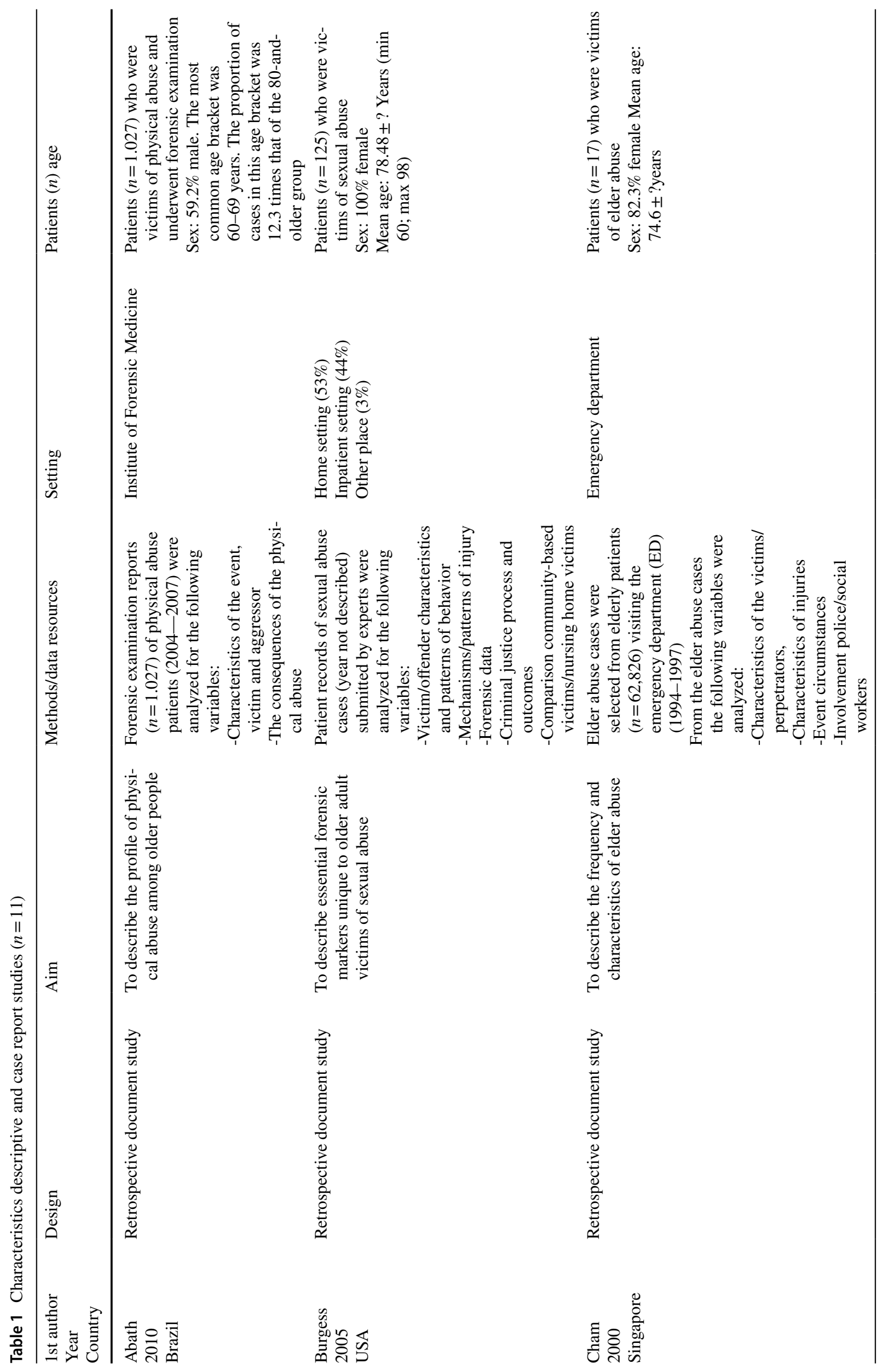




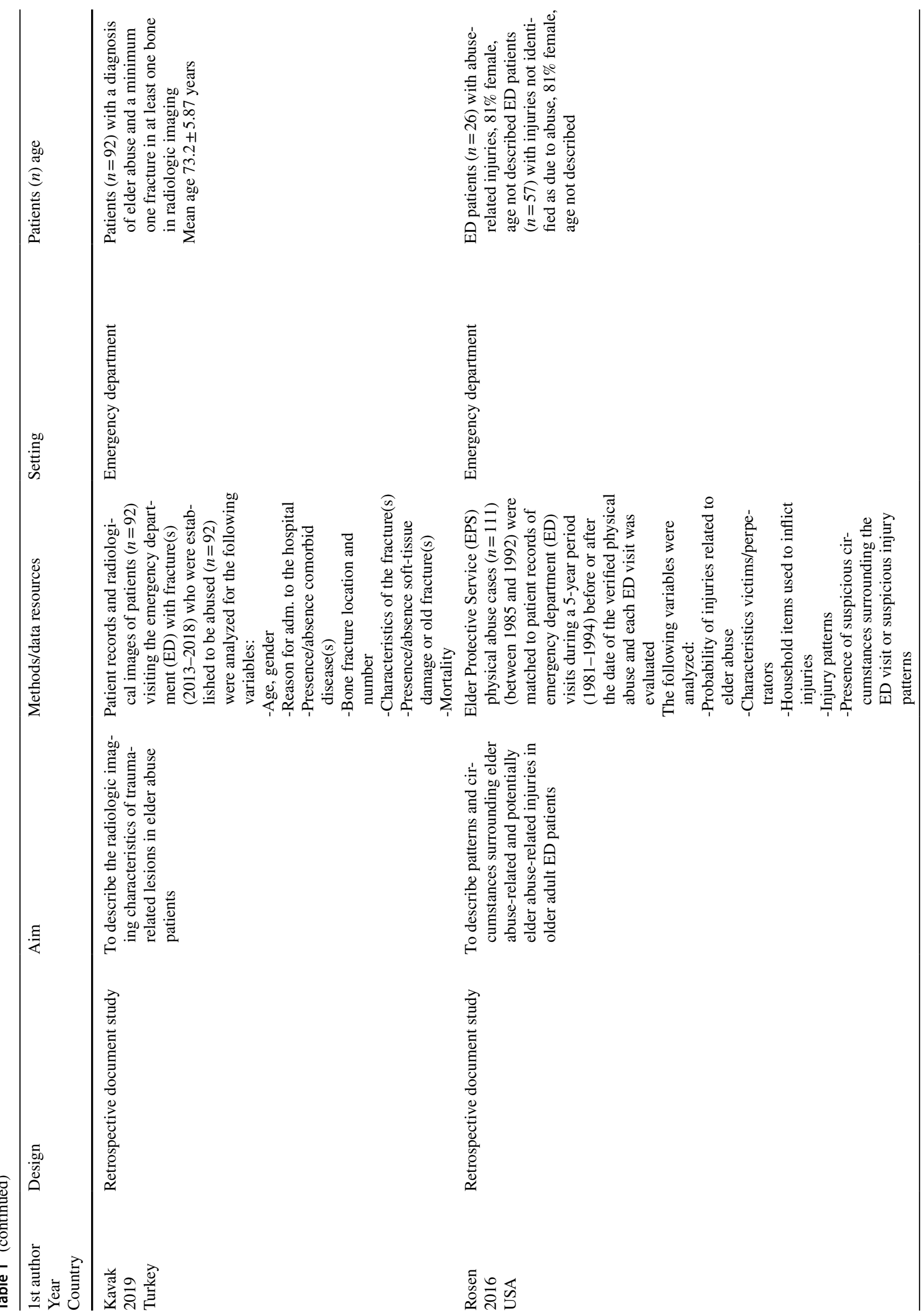




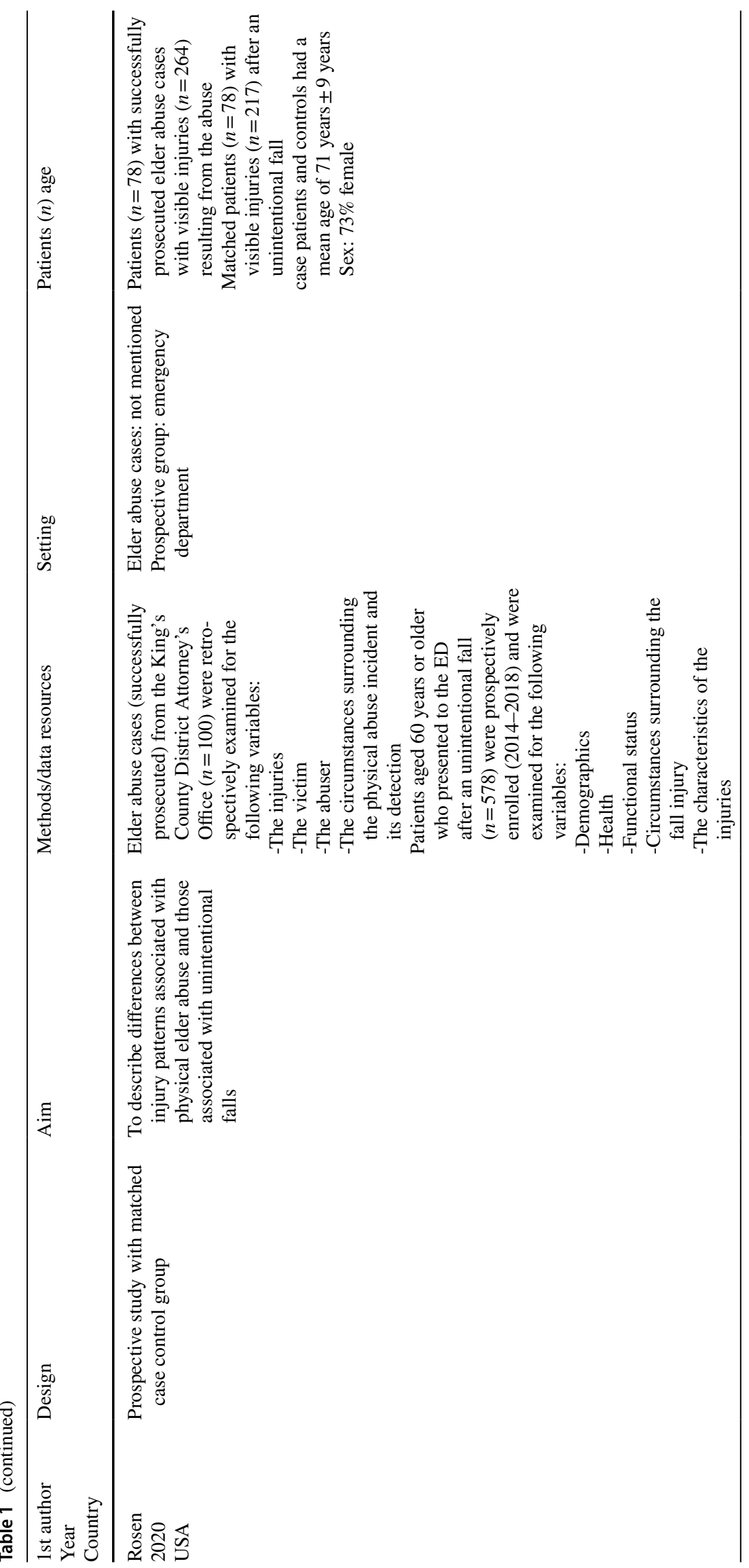




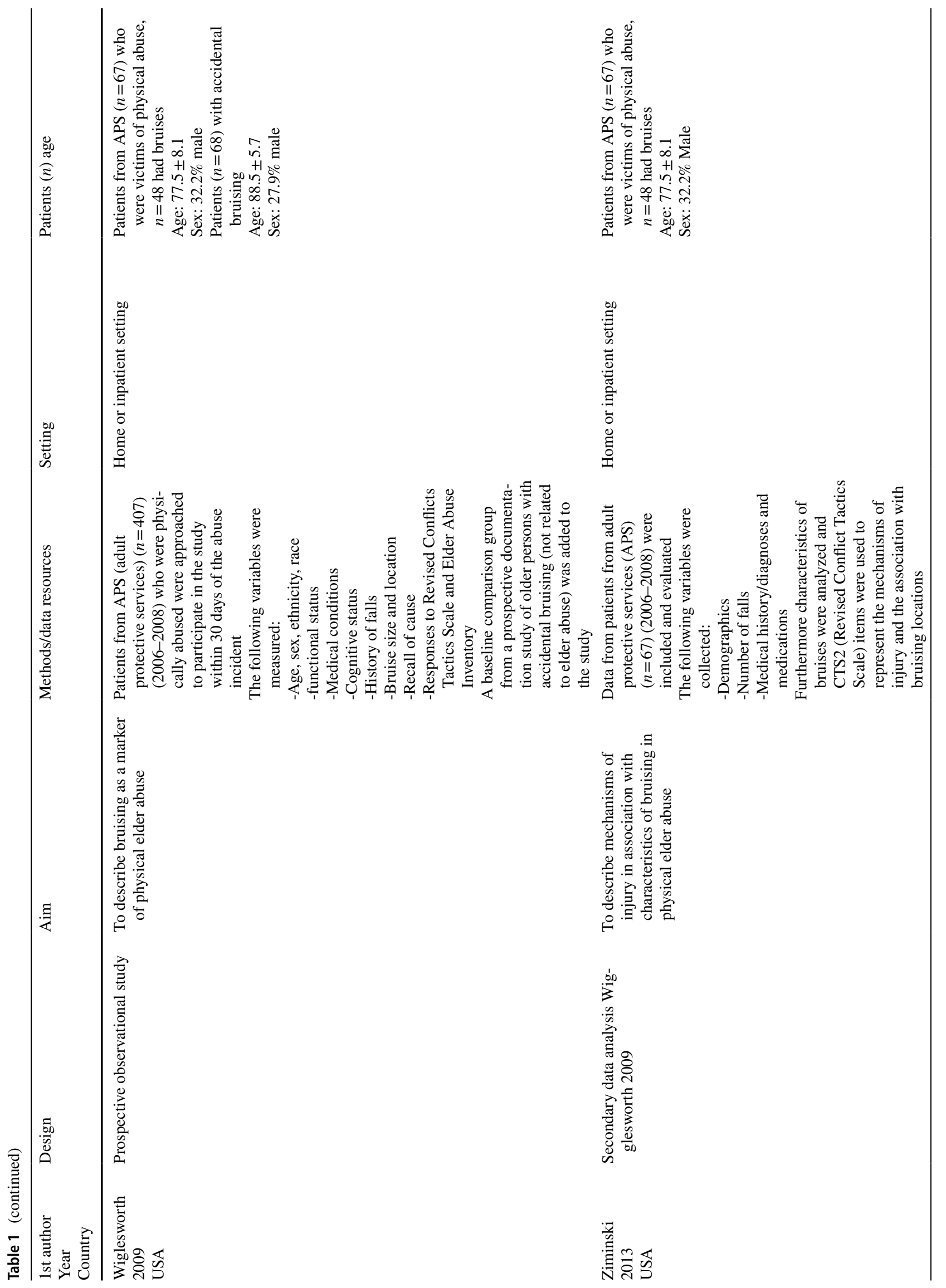




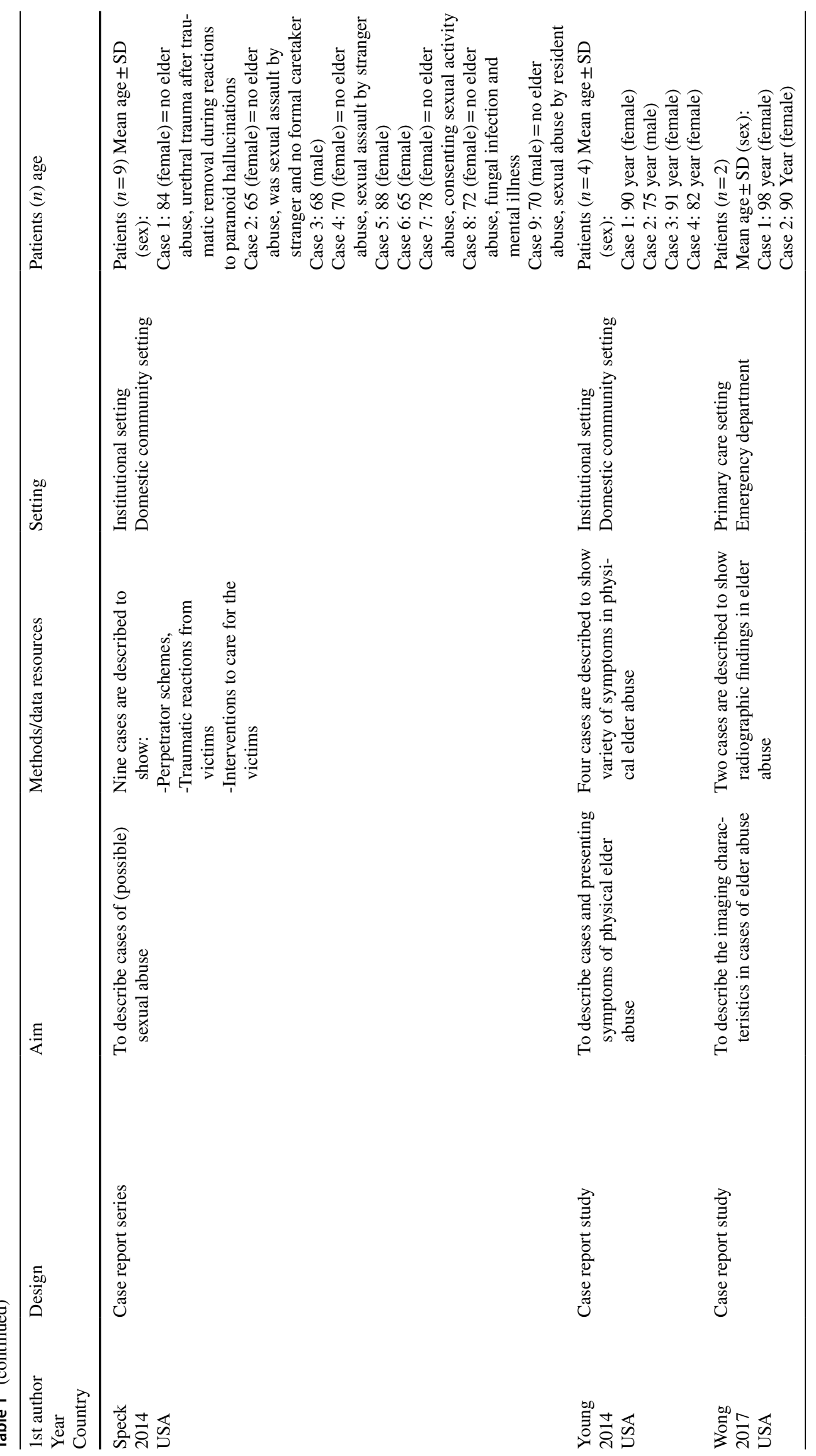


Table 2 Characteristics review studies $(n=5)$

\begin{tabular}{|c|c|c|c|c|c|c|}
\hline $\begin{array}{l}\text { 1st author } \\
\text { Year } \\
\text { Country }\end{array}$ & Design & Aim & Databases & Search strategy & Inclusion criteria & Included articles \\
\hline $\begin{array}{l}\text { Brown } \\
2004 \\
\text { Country not described }\end{array}$ & Review & $\begin{array}{l}\text { Aim not described, } \\
\text { overview regarding } \\
\text { position of nurse prac- } \\
\text { tioners in the inter- } \\
\text { vention and detection } \\
\text { of elder abuse }\end{array}$ & Not described & Not described & Not described & Not described \\
\hline $\begin{array}{l}\text { Clarysse } \\
2018 \\
\text { Belgium }\end{array}$ & Review & $\begin{array}{l}\text { To describe visible } \\
\text { injuries of physical } \\
\text { abuse, sexual abuse, } \\
\text { and neglect }\end{array}$ & Not described & Not described & Not described & Not described \\
\hline $\begin{array}{l}\text { Collins } \\
2006 \\
\text { USA }\end{array}$ & Review & $\begin{array}{l}\text { To describe current } \\
\text { medical and psycho- } \\
\text { logical understanding } \\
\text { of elder maltreatment }\end{array}$ & Not described & Not described & Not described & Not described \\
\hline $\begin{array}{l}\text { Murphy } \\
2013 \\
\text { Canada }\end{array}$ & Review & $\begin{array}{l}\text { To describe risk factors } \\
\text { and signs of elder } \\
\text { abuse }\end{array}$ & $\begin{array}{l}\text { 1. PubMed } \\
\text { 2. CINAHL } \\
\text { 3. EMBASE } \\
\text { 4. TRIP }\end{array}$ & $\begin{array}{l}\text { Databases were } \\
\text { searched from } 1975 \\
\text { to March } 2012 \text { using } \\
\text { the following words } \\
\text { and phrases: "physi- } \\
\text { cal elder abuse", } \\
\text { "older adult abuse", } \\
\text { "elder mistreatment", } \\
\text { "geriatric abuse", } \\
\text { "geriatric trauma", } \\
\text { and "nonaccidental } \\
\text { geriatric injury" in } \\
\text { the titles of articles. } \\
\text { Additional papers } \\
\text { identified through } \\
\text { reference lists } \\
\text { Exclusion criteria: arti- } \\
\text { cles non-pertinent or } \\
\text { duplication on screen- } \\
\text { ing of abstracts } \\
\text { To summarize all the } \\
\text { findings from these } \\
\text { studies, physical inju- } \\
\text { ries were classified } \\
\text { according to anatomic } \\
\text { location }\end{array}$ & $\begin{array}{l}\text { Description of the types } \\
\text { and distribution of } \\
\text { physical injuries in } \\
\text { elder abuse }\end{array}$ & $\begin{array}{l}9 \text { articles: } \\
1 \text { case report } \\
4 \text { case series } \\
2 \text { case-control } \\
\text { studies } \\
2 \text { cross-sectional } \\
\text { descriptive } \\
\text { studies }\end{array}$ \\
\hline $\begin{array}{l}\text { Pearsall } \\
2005 \\
\text { USA }\end{array}$ & Review & $\begin{array}{l}\text { To describe and analyze } \\
\text { forensic biomarkers } \\
\text { for elder abuse }\end{array}$ & Not described & Not described & Not described & Not described \\
\hline
\end{tabular}

\section{Data synthesis and presentation}

Due to the paucity of original studies, we analyzed and synthesized all studies, by scrutinizing and categorizing data. The case report data from the mixed methods studies were considered as original data and were therefore analyzed as case report studies. The primary outcomes were based on descriptive studies. Additionally, information from other study designs was added. First, studies were categorized according to their design or publication form. Second, three themes based on the taxonomy for visible intentional and unintentional acute injuries by Rosen et al. [20] were modified for this study and used for classification of the data extraction: (1) Types of physical signs. (2) Characteristics of physical signs. (3) Anatomic location of physical signs.

The following anatomic locations were chosen to categorize the physical signs:

1. Skull/brain/maxillofacial/dental/neck.

2. Chest/abdomen/back.

3. Extremities (upper/lower).

4. Pelvis/gluteal. 


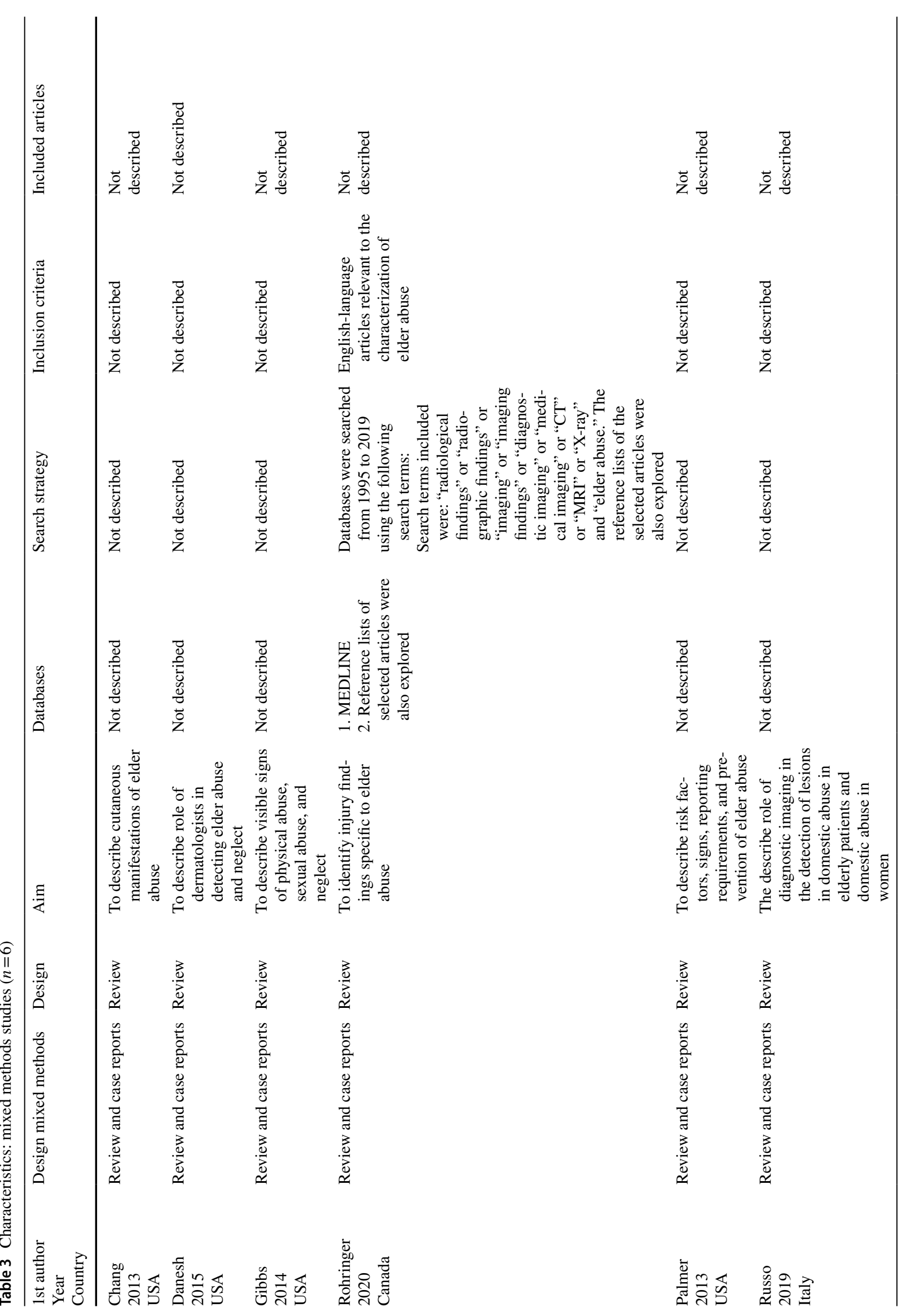




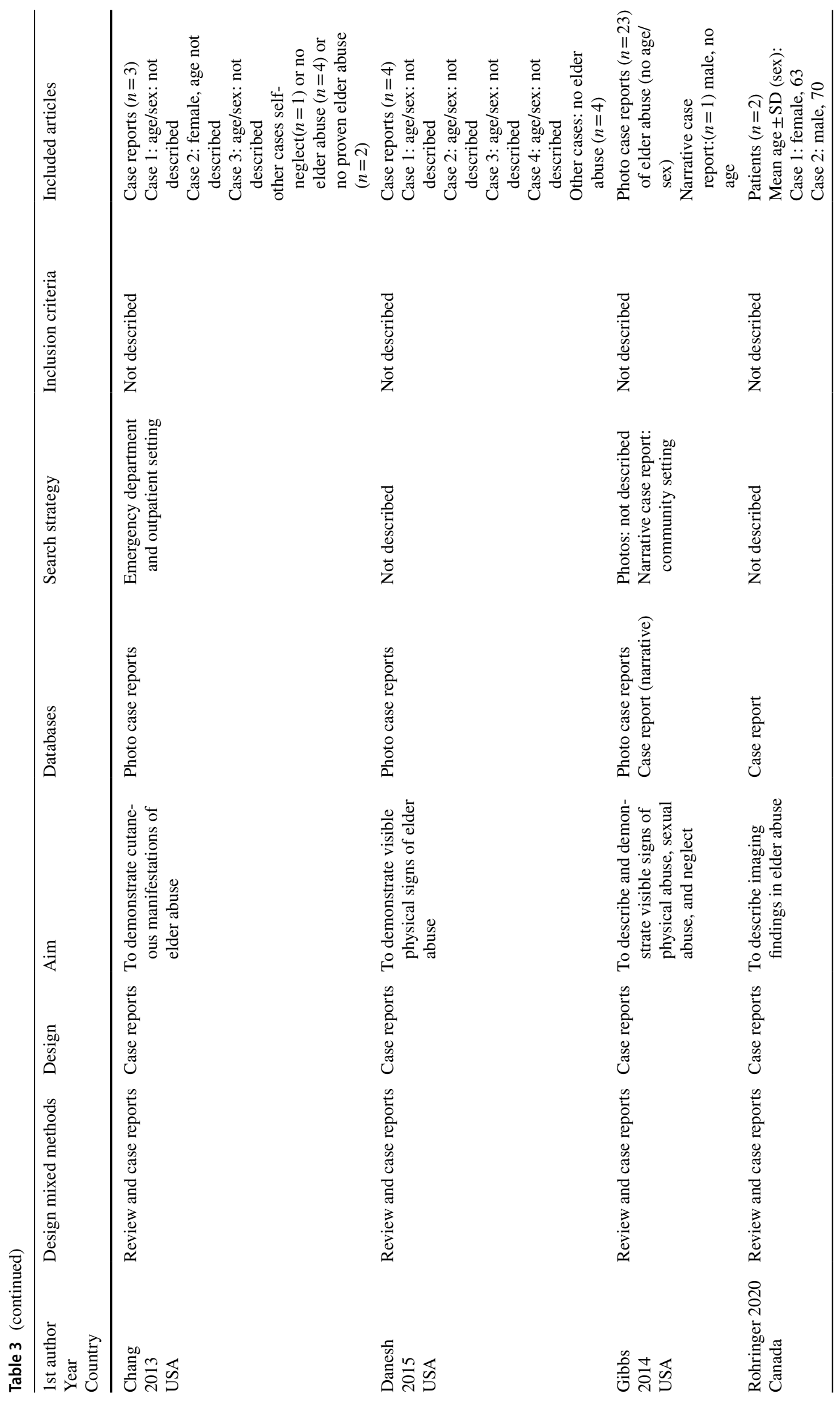




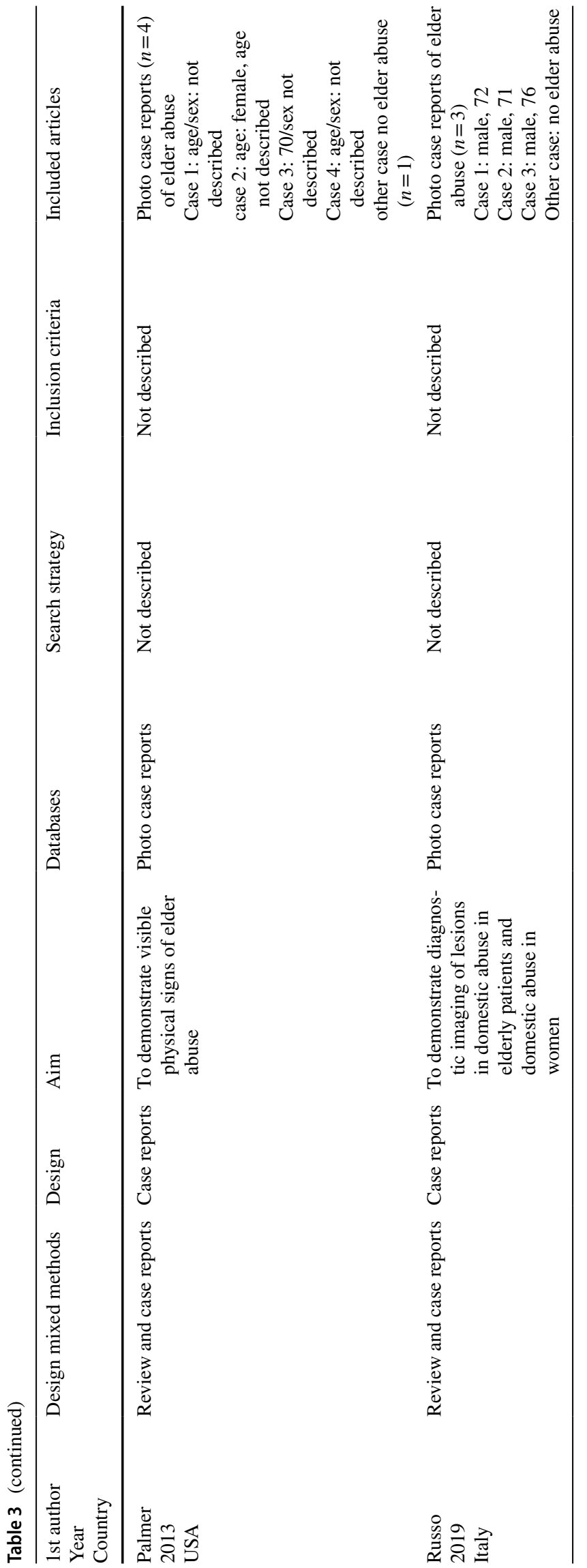

5. Extragenital in sexual elder abuse.

6. Miscellaneous.

\section{Results}

\section{Review statistics}

The initial search identified 5629 unique records, after the selection procedure 24 studies were included (see Fig. 1).

\section{Study characteristics}

The design of the included studies concerned eight descriptive studies [13, 21-27], three case studies [28-30], five narrative reviews [11, 31-34], six mixed methods studies [12, 35-39] and two books [40, 41]. See Tables 1, 2, 3 and 4 for characteristics studies.

\section{Quality assessment}

Most of the descriptive studies $(n=8)$ showed moderate to good quality [13, 21, 24, 26, 27].

Most of the mixed methods studies $(n=6)$ showed low quality [12, 35-37]. Despite the varying quality, all studies were included in our analysis. See Tables 5 and 6.

Outcomes: descriptive and case report studies (see Tables 7 and 8)

\section{Types of physical signs}

The most commonly described physical signs in elder abuse were bruises [12, 13, 22, 23, 25-27, 29, 30, 35-37].

\section{Characteristics of physical signs}

Wiglesworth et al. [13] described that with regard to the size of physical signs, bruises related to physical elder abuse are often large, e.g., $>5 \mathrm{~cm}$ wide at its widest point. Other studies described that with regard to the shape of physical signs, bruises and injuries related to elder abuse can be body part marked, e.g., the presence of thumb and finger marks (fingertip bruising) or object marked, e.g., ligature bruising or tramline bruising due to beating with a narrow shaped object $[12,22,35,37]$. Furthermore studies described that the distribution of physical signs in a stocking or glove distribution (e.g., due to immersion of the extremities in hot water), the presence of a cutaneous casal necklace (dermatitis around the neck due to vitamin B3 deficiency in case of neglect), and injuries in multiple stages of healing or multifocal fractures to be caused by elder abuse [30, 36]. No description 
Table 4 Characteristics books $(n=2)$

\begin{tabular}{|c|c|c|c|}
\hline $\begin{array}{l}\text { 1st author } \\
\text { Year } \\
\text { Country }\end{array}$ & Design & Aim & Content \\
\hline $\begin{array}{l}\text { Baccino } \\
2020 \\
\text { France }\end{array}$ & Book & Not described & $\begin{array}{l}\text { The title of the chapter is "Imaging and Elderly abuse" } \\
\text { Described are: } \\
\text { 1. Background of elder abuse: definitions, epidemiology, signs and diagnosis } \\
\text { 2. Particularities of imaging in elderly } \\
\text { 3. Some imaging findings in elder abuse }\end{array}$ \\
\hline $\begin{array}{l}\text { Dyer } \\
2002 \\
\text { USA }\end{array}$ & Book & Not described & $\begin{array}{l}\text { The title of the chapter is "The clinical and Medical Forensics of Elder Abuse } \\
\text { and Neglect". Described are several potential forensic markers of elder } \\
\text { abuse and neglect }\end{array}$ \\
\hline
\end{tabular}

of characteristics of physical signs were given in six out of eight descriptive studies [21, 23-27], two out of nine case report studies (primary case report studies) [28, 29], and two out of six mixed methods studies [38, 39].

\section{Anatomic location of physical signs}

Anatomic locations of physical signs in elder abuse were described to be predominantly on the head, face/maxillofacial area (including eyes, ears and dental area), neck, upper extremities and torso (especially posterior). Other anatomic locations mentioned to be associated with elder abuse included the lower extremities, abdomen, lumbar area and gluteal/genital/rectal area, the latter location often mentioned as being associated with the presence of sexual elder abuse or neglect (e.g., decubitus ulcers) [12, 13, 21-27, 29, 30, 35-39].

Some studies described physical signs due to elder abuse to be specifically located on the left respectively right side of the body [13, 24, 26, 27, 30, 38, 39]. Furthermore Rosen et al. [26] described that physical abuse victims were more likely to have visible injuries in the maxillofacial, dental or neck area without the presence of injuries to the upper or lower extremities. Also, certain anatomic locations of bruises were described to be related to the mechanism of injury. The odds that a person had head and neck bruises were greater in case they were choked, punched and beaten up than in persons who did not report being choked, punched and beaten up. The odds of having bruises on the lateral/ anterior arm were greater when persons reported to be grabbed compared to persons who did not report being grabbed [27]. Physical signs related to sexual elder abuse were mostly located in vestibular and vaginal tissues (petechiae), the labia minora and majora (bruising), posterior fourchette (bruising) and the perianal area (contusions). Victims of sexual elder abuse were furthermore described to have a significant amount of injury located at non-genital parts of their body, especially to their head and arms and on the medial aspect of the thigh [12, 22, 36]. Physical signs of sexual elder abuse in males were not found. In the article of
Speck et al. 2014, only two cases of sexual abuse in males were described. Only one case was defined as sexual elder abuse, but in this case signs of physical injury were lacking [28]. Physical signs related to neglect were described as cutaneous lesions due to vitamin deficiency, poor oral dentition, physical signs on the surface of the skin due to untreated skin cancer or moisture, decubitus ulcers in the sacrum, buttocks, thighs and stage I-III decubitus ulcers on heels [36, 37].

\section{Additional outcomes (see Table 9)}

Additional outcomes of elder abuse were diverse and involved wounds and unexplainable injuries, combinations of injuries, mechanism of injuries, sexual elder abuse and neglect in victims. Additional characteristics of physical signs were deep and/or foul-smelling necrotic aspects of ulcers, bilateral or parallel and irregular injuries, multiple and clustered injuries, circular bruising, splash marks from hot water and traumatic/irregular patches of alopecia. Although the color of bruises was stated not reliable for the dating of bruises, bruises with differing colors may point at recurrent abuse [12, 32, 33, 35, 37, 41]. Anatomic locations of specific injuries in elder abuse were: a basilar skull fracture due to elder abuse (raccoon sign or periorbital ecchymosis) and bruising over the mastoid process (battle sign). In (attempted) strangulation, the following physical signs were described: abrasions on anterior neck and petechiae on neck, head, face, eyes, ears, conjunctivae and buccal mucosa [37]. Additionally to the anatomic locations of physical signs, it was mentioned that bruising to the ulnar side of the forearms of victims of elder abuse was often combined with the presence of a fracture of the distal ulnar diaphysis, and that bruising to the posterior torso was often combined with rib fractures [38]. Finally, injuries to palms and dorsal or plantar soles of the feet were also mentioned as physical signs of elder abuse. In victims of sexual elder abuse, additional anatomic locations of physical signs were unexplained sexually transmitted diseases (located on genital area or skin or oral area), pain or bleeding from the genital area, bruising 
Table 5 Quality of descriptive studies $(n=8)$

\begin{tabular}{|c|c|c|c|c|c|c|c|c|}
\hline Criteria/ First author & $\begin{array}{l}\text { Abath } \\
2010 \\
\text { Brasil }\end{array}$ & $\begin{array}{l}\text { Burgess } \\
2005 \\
\text { USA }\end{array}$ & $\begin{array}{l}\text { Cham } \\
2000 \\
\text { Singapore }\end{array}$ & $\begin{array}{l}\text { Kavak } \\
2019 \\
\text { Turkey }\end{array}$ & $\begin{array}{l}\text { Rosen } \\
2016 \\
\text { USA }\end{array}$ & $\begin{array}{l}\text { Rosen } \\
2020 \\
\text { USA }\end{array}$ & $\begin{array}{l}\text { Wigles- } \\
\text { worth } 2009 \\
\text { USA }\end{array}$ & $\begin{array}{l}\text { Ziminski } \\
2013 \\
\text { USA }\end{array}$ \\
\hline $\begin{array}{l}\text { Question / objective } \\
\text { sufficiently described? }\end{array}$ & $\oplus$ & $\oplus$ & $\oplus$ & $\oplus$ & $\oplus$ & $\oplus$ & $\oplus$ & $\oplus$ \\
\hline $\begin{array}{l}\text { Study design evident } \\
\text { and appropriate? }\end{array}$ & $\oplus$ & $\oplus$ & $\oplus$ & $\oplus$ & $\oplus$ & $\oplus$ & $\oplus$ & $\oplus$ \\
\hline $\begin{array}{l}\text { Method of subject } \\
\text { /comparison group } \\
\text { selection or source of } \\
\text { information/ } \\
\text { input variables } \\
\text { described and } \\
\text { appropriate? } \\
\end{array}$ & $\oplus$ & $\oplus$ & $\oplus$ & $\oplus$ & $\oplus$ & $\oplus$ & $\oplus$ & $\oplus$ \\
\hline $\begin{array}{l}\text { Subject (and } \\
\text { comparison group) } \\
\text { characteristics } \\
\text { sufficiently described? }\end{array}$ & $\oplus$ & $\oplus$ & $\oplus$ & $\oplus$ & $\oplus$ & $\oplus$ & $\oplus$ & $\oplus$ \\
\hline $\begin{array}{l}\text { Outcome and exposure } \\
\text { measure(s) well } \\
\text { defined and robust to } \\
\text { measurement / } \\
\text { misclassification bias? } \\
\text { means of assessment } \\
\text { reported? }\end{array}$ & $\Theta$ & $\oplus$ & $\oplus$ & $\oplus$ & $\oplus$ & $\oplus$ & $\oplus$ & $\oplus$ \\
\hline $\begin{array}{l}\text { Sample size } \\
\text { appropriate? }\end{array}$ & N/A & N/A & N/A & N/A & N/A & N/A & N/A & N/A \\
\hline $\begin{array}{l}\text { Analytic methods } \\
\text { described/justified and } \\
\text { appropriate? }\end{array}$ & $\oplus$ & $\oplus$ & $\oplus$ & $\oplus$ & $\oplus$ & $\oplus$ & $\oplus$ & $\oplus$ \\
\hline $\begin{array}{l}\text { Some estimate of } \\
\text { variance is reported for } \\
\text { the main results? }\end{array}$ & $\Theta$ & $\Theta$ & $\Theta$ & $\oplus$ & $\Theta$ & $\oplus$ & $\oplus$ & $\oplus$ \\
\hline $\begin{array}{l}\text { Controlled for } \\
\text { confounding? }\end{array}$ & N/A & N/A & N/A & N/A & N/A & N/A & N/A & N/A \\
\hline $\begin{array}{l}\text { Results reported in } \\
\text { sufficient detail? }\end{array}$ & $\oplus$ & $\oplus$ & $\oplus$ & $\oplus$ & $\oplus$ & $\oplus$ & $\oplus$ & $\oplus$ \\
\hline $\begin{array}{l}\text { Conclusions supported } \\
\text { by the results? }\end{array}$ & $\oplus$ & $\oplus$ & $\oplus$ & $\oplus$ & $\oplus$ & $\oplus$ & $\oplus$ & $\oplus$ \\
\hline Summary score & 0.55 & 0.72 & 0.77 & 1.0 & 0.77 & 1.0 & 1.0 & 1.0 \\
\hline
\end{tabular}

$\oplus$ Yes $\oplus$ Partial $\odot$ No, N/A: not applicable; Total sum $=($ number of "yes" * 2) + (number of "partials" * 1); Total possible sum $=22-$ (number of "N/A" *2); Summary score: total sum/total possible sum; please note: 22 instead of 28 total possible sum because of only 11 items instead of 14 items

to the uvula or the palate and lacerations to inner lips and buccal mucosa [32, 33, 35]. In case of neglect, dry mucous membranes, sunken eyes or decreased skin turgor in dehydration and poor general hygiene were described [12, 37].

\section{Discussion}

The most commonly described physical signs in elder abuse were bruises. Characteristics of physical signs could be categorized into size, shape and distribution. Physical signs were 
Table 6 Quality of mixed methods studies $(n=6)$

\begin{tabular}{|c|c|c|c|c|c|c|}
\hline Criteria/first author & $\begin{array}{l}\text { Chang } \\
2013 \\
\text { USA }\end{array}$ & $\begin{array}{l}\text { Danesh } \\
2015 \\
\text { USA }\end{array}$ & $\begin{array}{l}\text { Gibbs } \\
2014 \\
\text { USA }\end{array}$ & $\begin{array}{l}\text { Rohringer } \\
2020 \\
\text { Canada }\end{array}$ & $\begin{array}{l}\text { Palmer } \\
2013 \\
\text { USA }\end{array}$ & $\begin{array}{l}\text { Russo } \\
2019 \\
\text { Italy }\end{array}$ \\
\hline $\begin{array}{l}\text { Is there an adequate rationale for using a mixed methods design to } \\
\text { address the research question? }\end{array}$ & Can’t tell & Can’t tell & Can’t tell & Yes & Can't tell & Yes \\
\hline $\begin{array}{l}\text { Are the different components of the study effectively integrated to } \\
\text { answer the research question? }\end{array}$ & Yes & Yes & Yes & Yes & Yes & Yes \\
\hline $\begin{array}{l}\text { Are the outputs of the integration of qualitative and quantitative compo- } \\
\text { nents adequately interpreted? }\end{array}$ & Yes & Yes & Yes & Yes & Yes & Yes \\
\hline $\begin{array}{l}\text { Are divergences and inconsistencies between quantitative and qualita- } \\
\text { tive results adequately addressed? }\end{array}$ & No & No & No & No & No & No \\
\hline $\begin{array}{l}\text { Do the different components of the study adhere to the quality criteria } \\
\text { of each tradition of the methods involved? }\end{array}$ & No & No & No & Yes & No & No \\
\hline
\end{tabular}

anatomically predominantly located on the head, face/maxillofacial area (including eyes, ears and dental area), neck, upper extremities and torso (especially posterior). Physical signs related to sexual elder abuse were mostly located in vestibular and vaginal tissues, the labia minora and majora, posterior fourchette and the perianal area. Victims of sexual elder abuse were furthermore described to have a significant amount of injury located at non-genital parts of their body, especially on their head and arms and the medial aspect of the thigh. Unfortunately, with regard to the characteristics and anatomical location of physical signs in sexual elder abuse in older males, information was absent.

This is the first systematic review on the state-of-the-art knowledge on physical signs in elder abuse where a quality analysis of observational studies was performed and additional findings of other designs were included. Furthermore, physical signs were described and classified along the lines of the taxonomy instrument for visible intentional and unintentional acute injuries based on the study by Rosen et al. [20]. By identifying the types, characteristics and anatomic location of physical signs in elder abuse, this review contributes to the awareness and recognition of elder abuse by clinical geriatricians and other healthcare professionals. Detecting specific injury patterns suggestive of elder abuse can aid healthcare professionals in their physical examination and strengthen the need for a head to toe examination. The use of a taxonomy instrument for a structured and uniform description of characteristics and location of physical signs in elder abuse can help healthcare professionals to systematically assess physical signs, especially in situations where it is not easy to discriminate from signs of other underlying diseases. To move forward on the road to early detection and awareness of physical and other signs of elder abuse, it is necessary to invest in education. In contrast to pediatricians educated in the recognition of and care for child abuse victims, education on the recognition of physical signs in elder abuse (and other signs of elder abuse, e.g., in financial and physiological abuse) is not yet common for clinical geriatricians and other healthcare professionals (such as nurses) in clinical care. Also, the sense of ownership and commitment regarding the recognition and care of elder abuse victims is not yet self-evident in geriatric healthcare professionals. The authors of this review strongly recommend education on this topic, not only for clinical geriatricians but for all other healthcare professionals with a caseload of older patients. Furthermore, to effectively deal with elder abuse, a systematic screening for a timely identification of signals, as well as a systematic approach in case elder abuse is (suspected to be) present, is necessary. With regard to an effective screening on elder abuse, no single tool has yet been found appropriate [42, 43]. In absence of an appropriate validated tool for signalling elder abuse, the Dutch guideline on (suspected) elder abuse [17] recommends that healthcare professionals working in the hospital setting should be aware of an internal sense of alarm with regard to the (possible) presence of elder abuse, by asking themselves a "gut feeling" question in $70+$ individuals that visit the hospital setting. Unfortunately, effective screening on elder abuse is not enough. It is equally important to have an adequate approach and followup process in each hospital or nursing home, when cases of elder abuse are suspected and/or present. Since 1 July 2013, it is mandatory for professionals in the Netherlands to follow a mandatory reporting code in case of (suspected) domestic violence and child abuse (source: Government of the Netherlands (https://www.government.nl/topics/domes tic-violence/domestic-violence-and-child-abuse-protocol). In the Netherlands, elder abuse is categorized as a form of domestic violence and thus in case of elder abuse the mandatory reporting code in case of (suspected) domestic violence and child abuse is followed. Cases of elder abuse as a result of abuse by healthcare professionals are primarily reported to the healthcare inspectorate.

The reporting code offers a five-step plan detailing the best course of action and helps healthcare professionals 
Table 7 Results descriptive and case report studies: types elder abuse and physical signs

\begin{tabular}{|c|c|c|}
\hline $\begin{array}{l}\text { 1st author } \\
\text { (Year) } \\
\text { Country }\end{array}$ & Types: elder abuse & Types: physical signs \\
\hline \multicolumn{3}{|c|}{ Descriptive studies } \\
\hline $\begin{array}{l}\text { Abath } \\
2010 \\
\text { Brazil }\end{array}$ & 1. PA & 1. Burns \\
\hline $\begin{array}{l}\text { Burgess } \\
2005 \\
\text { USA }\end{array}$ & 1. SA & $\begin{array}{l}\text { 1. Abrasions } \\
\text { 2. Bruises }\end{array}$ \\
\hline $\begin{array}{l}\text { Cham } \\
2000 \\
\text { Singapore }\end{array}$ & 1. PA & $\begin{array}{l}\text { 1. Blunt trauma } \\
\text { 2. Bruises } \\
\text { 2. Contusions } \\
\text { 3. Dehydration } \\
\text { 4. Fracture }\end{array}$ \\
\hline $\begin{array}{l}\text { Kavak } \\
2019 \\
\text { Turkey }\end{array}$ & $\begin{array}{l}\text { 1. PA } \\
\text { 2. N } \\
\text { 3. PsA } \\
\text { 4. FA }\end{array}$ & $\begin{array}{l}\text { 1. Fractures } \\
\text { 2. Soft tissue lesions }\end{array}$ \\
\hline $\begin{array}{l}\text { Rosen } \\
2016 \\
\text { USA }\end{array}$ & 1. PA & $\begin{array}{l}\text { 1. Bruises } \\
\text { 2. Fracture } \\
\text { 3. Hematoma (subdural) } \\
\text { 4. Laceration }\end{array}$ \\
\hline $\begin{array}{l}\text { Rosen } \\
2020 \\
\text { USA }\end{array}$ & 1. PA & $\begin{array}{l}\text { 1. Abrasion } \\
\text { 2. Bruises } \\
\text { 3. Fractures } \\
\text { 4. Laceration } \\
\text { 5. Skin tear }\end{array}$ \\
\hline $\begin{array}{l}\text { Wiglesworth } \\
2009 \\
\text { USA }\end{array}$ & 1. PA & 1. Bruises \\
\hline $\begin{array}{l}\text { Ziminski } \\
2013 \\
\text { USA }\end{array}$ & 1. PA & 1. Bruises \\
\hline \multicolumn{3}{|c|}{ Case report studies } \\
\hline $\begin{array}{l}\text { Chang } \\
2013 \\
\text { USA }\end{array}$ & 1. PA & $\begin{array}{l}\text { 1. Abrasions } \\
\text { 2. Bruises } \\
\text { 3. Defensive injury }\end{array}$ \\
\hline $\begin{array}{l}\text { Danesh } \\
2015 \\
\text { USA }\end{array}$ & $\begin{array}{l}\text { 1. PA } \\
\text { 2. N } \\
\text { 3. SA }\end{array}$ & $\begin{array}{l}\text { 1. Bruises } \\
\text { 2. Burns } \\
\text { 3. Contusions } \\
\text { 4. Defensive injury } \\
\text { 5. Signs of nutritional deficiency }\end{array}$ \\
\hline $\begin{array}{l}\text { Gibbs } \\
2014 \\
\text { USA }\end{array}$ & $\begin{array}{l}\text { 1. PA } \\
\text { 2. SN } \\
\text { 3. SA }\end{array}$ & $\begin{array}{l}\text { 1. Abrasion } \\
\text { 2. Blunt trauma } \\
\text { 3. Bruises } \\
\text { 4. Burn } \\
\text { 5. Hematoma } \\
\text { 6. Laceration } \\
\text { 7. Moisture-associated.skin damage } \\
\text { 8. Poor oral dentition } \\
\text { 9. Pressure sore/ulcer (decubitus, pressure) } \\
\text { 10. Untreated skin cancer }\end{array}$ \\
\hline $\begin{array}{l}\text { Palmer } \\
2013 \\
\text { USA }\end{array}$ & $\begin{array}{l}\text { 1. PA } \\
\text { 2. SN } \\
\text { 3. SA }\end{array}$ & $\begin{array}{l}\text { 1. Bruises } \\
\text { 2. Ligature marks }\end{array}$ \\
\hline $\begin{array}{l}\text { Rohringer } \\
2020 \\
\text { Canada }\end{array}$ & 1. PA & $\begin{array}{l}\text { 1. Contusion } \\
\text { 2. Hematoma } \\
\text { 3. Fracture } \\
\text { 4. Soft tissue swelling }\end{array}$ \\
\hline
\end{tabular}


Table 7 (continued)

\begin{tabular}{|c|c|c|}
\hline $\begin{array}{l}\text { 1st author } \\
\text { (Year) } \\
\text { Country }\end{array}$ & Types: elder abuse & Types: physical signs \\
\hline $\begin{array}{l}\text { Russo } \\
2019 \\
\text { Italy }\end{array}$ & 1. PA & $\begin{array}{l}\text { 1. Contusion } \\
\text { 2. Fractures }\end{array}$ \\
\hline $\begin{array}{l}\text { Speck } \\
2014 \\
\text { USA }\end{array}$ & 1. SA & 1. Petechiae \\
\hline $\begin{array}{l}\text { Young } \\
2014 \\
\text { USA }\end{array}$ & $\begin{array}{l}\text { 1. PA } \\
\text { 2. N }\end{array}$ & $\begin{array}{l}\text { 1. Bruises } \\
\text { 2. Dislocation } \\
\text { 3. Fractures } \\
\text { 4. Ulcers }\end{array}$ \\
\hline $\begin{array}{l}\text { Wong } \\
2017 \\
\text { USA }\end{array}$ & 1. EA & $\begin{array}{l}\text { 1. Fractures } \\
\text { 2. Bruises } \\
\text { 3. Hematoma } \\
\text { 4. Hemorrhage } \\
\text { 5. Ecchymosis }\end{array}$ \\
\hline
\end{tabular}

$E A$ elder abuse, $P A$ physical abuse, $S A$ sexual abuse, $N$ neglect, $S N$ self-neglect, $P S A$ psychological abuse, $F A$ financial abuse

in and outside (clinical) geriatric care to decide whether or not to report the situation to the Adult Protective Services (APS). In addition, within each hospital or institutional setting caring for older persons, it would be advisable to appoint a case manager on domestic violence and elder abuse, to coordinate and guide compliance with the follow-up of the reporting code and to support and advise the healthcare professional in the recognition and care for victims of elder abuse. The installation of an additional Multidisciplinary Elder Abuse Team (MEAT), where cases of elder abuse victims are (anonymously) discussed and course of action is evaluated, could further enhance a multidisciplinary approach to elder abuse investigation. Participants should at minimum include clinical geriatric and emergency medicine experts (nurses and physicians), a case manager on domestic violence and elder abuse, a social worker and a representative of the regional Adult Protective Services. With regard to the recognition of physical signs in elder abuse, it would be advisory not only to include forensic expertise from a forensic physician or a forensic trained nurse in the multidisciplinary elder abuse team, but also to incorporate them as a consultant in the acute setting. They can help recognize and safeguard forensic evidence during the assessment process. Finally, thorough reporting and transfer to healthcare professionals during discharge/care transition is essential in this process.

A key limitation of this systematic review is that the primary data studies had moderate methodological quality and included only a limited number of studies with a (matched) control group. Furthermore, the narrative reviews mainly summarized the included observational descriptive studies.
However, with this review, a contribution and an incentive to achieve higher methodological research quality in the field of elder abuse have been made, as pitfalls in existing knowledge on physical signs of elder abuse have been identified. More research regarding for example pathognomic injuries in elder abuse could eventually provide healthcare professionals with (more) practical knowledge on adequate and timely recognition of physical signs in elder abuse.

\section{Conclusions}

- The most commonly described physical signs in elder abuse are bruises.

- Older persons are more likely to have physical signs of elder abuse located on the head, face/maxillofacial area (including eyes, ears and dental area), neck, upper extremities and torso (especially posterior).

- Physical signs related to sexual elder abuse are mostly located in the genital and perianal area and are often accompanied by a significant amount of injury to nongenital parts of their body, especially to the area of the head, arms and the medial aspect of the thigh.

- The characteristics and anatomical location of physical signs in sexual elder abuse in males needs to be explored in future research.

- Knowledge regarding the most common types, characteristics and anatomic location of physical signs in elder abuse is useful to increase the awareness and recognition of elder abuse by clinical geriatricians and other healthcare professionals. 


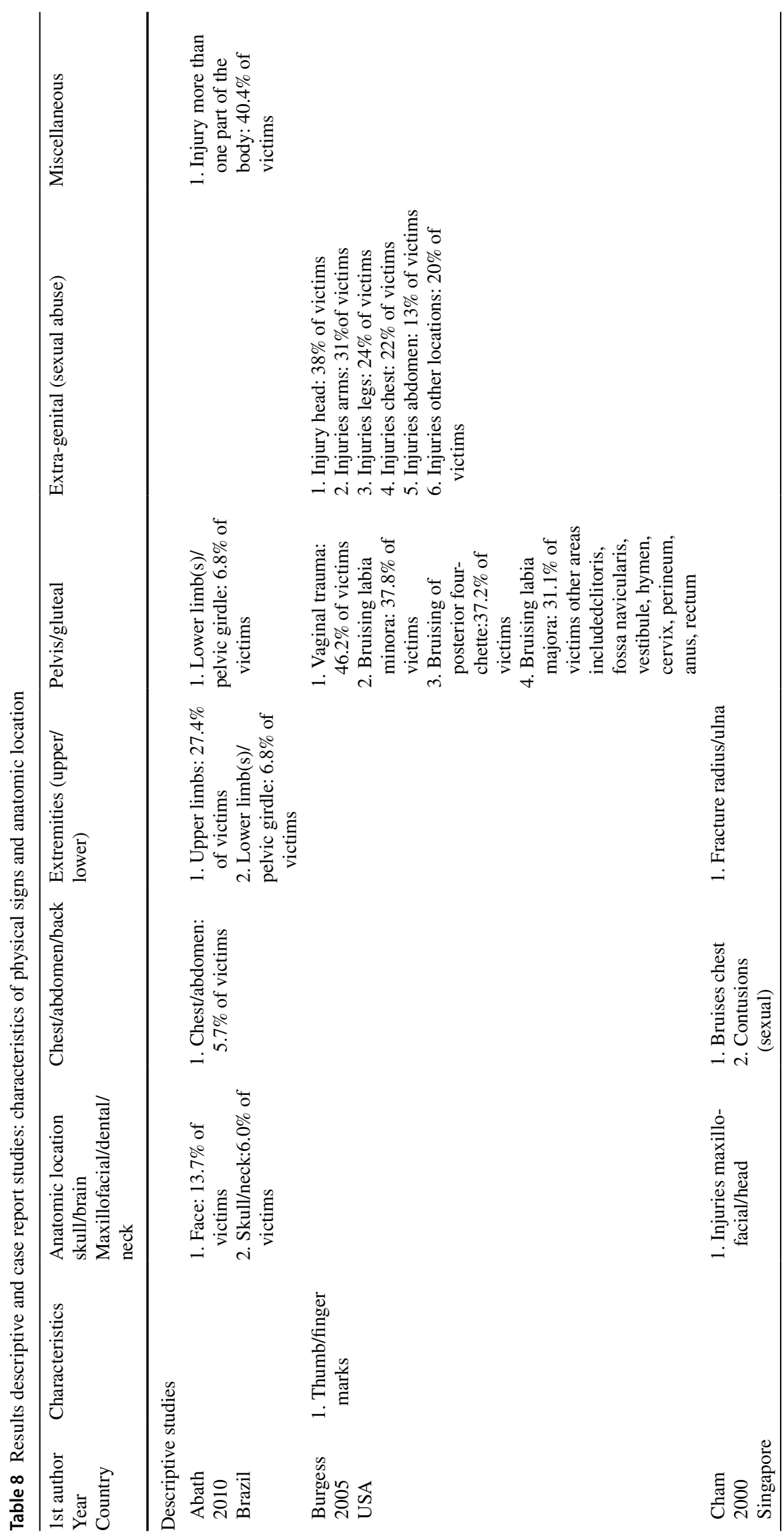




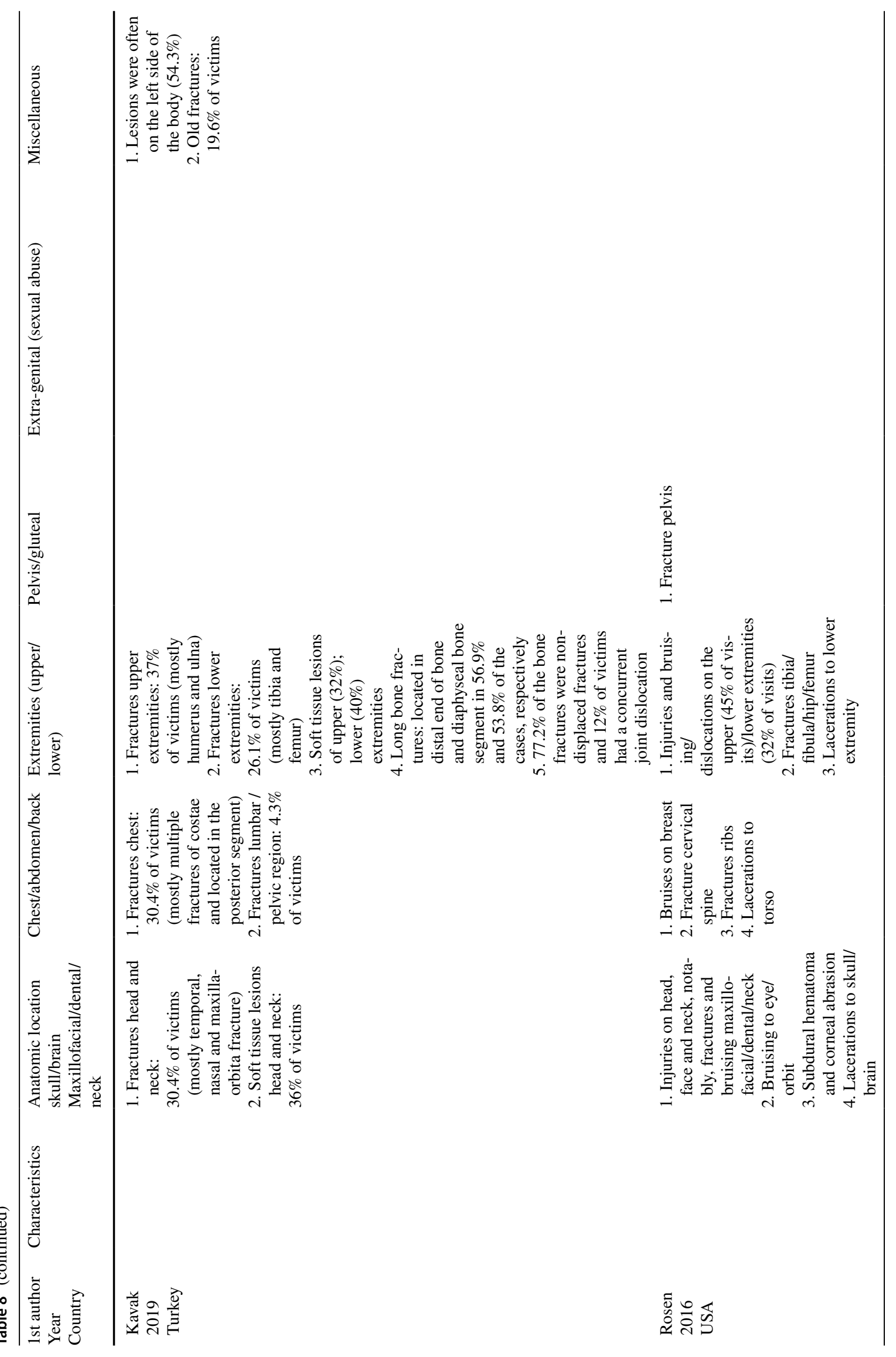




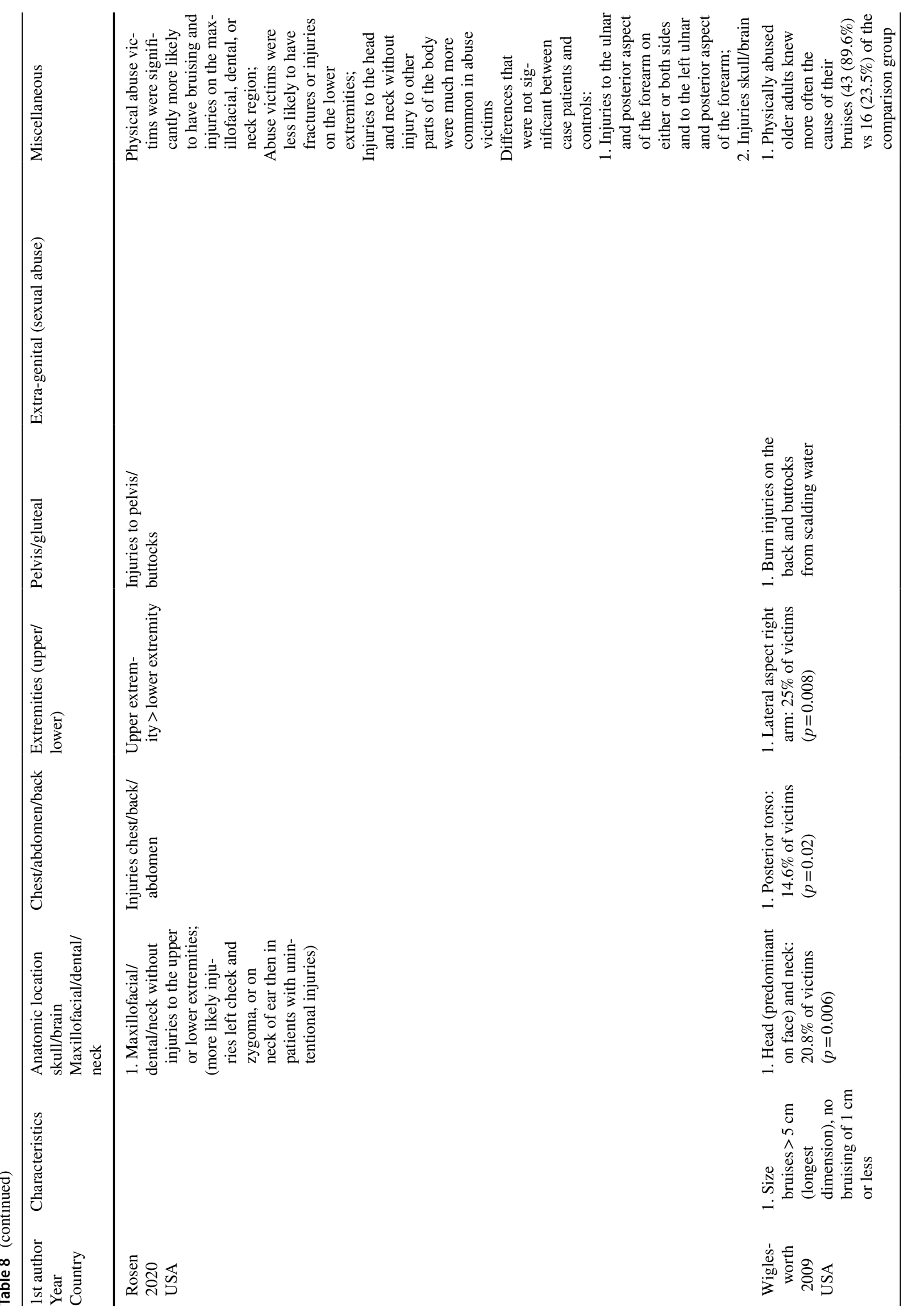




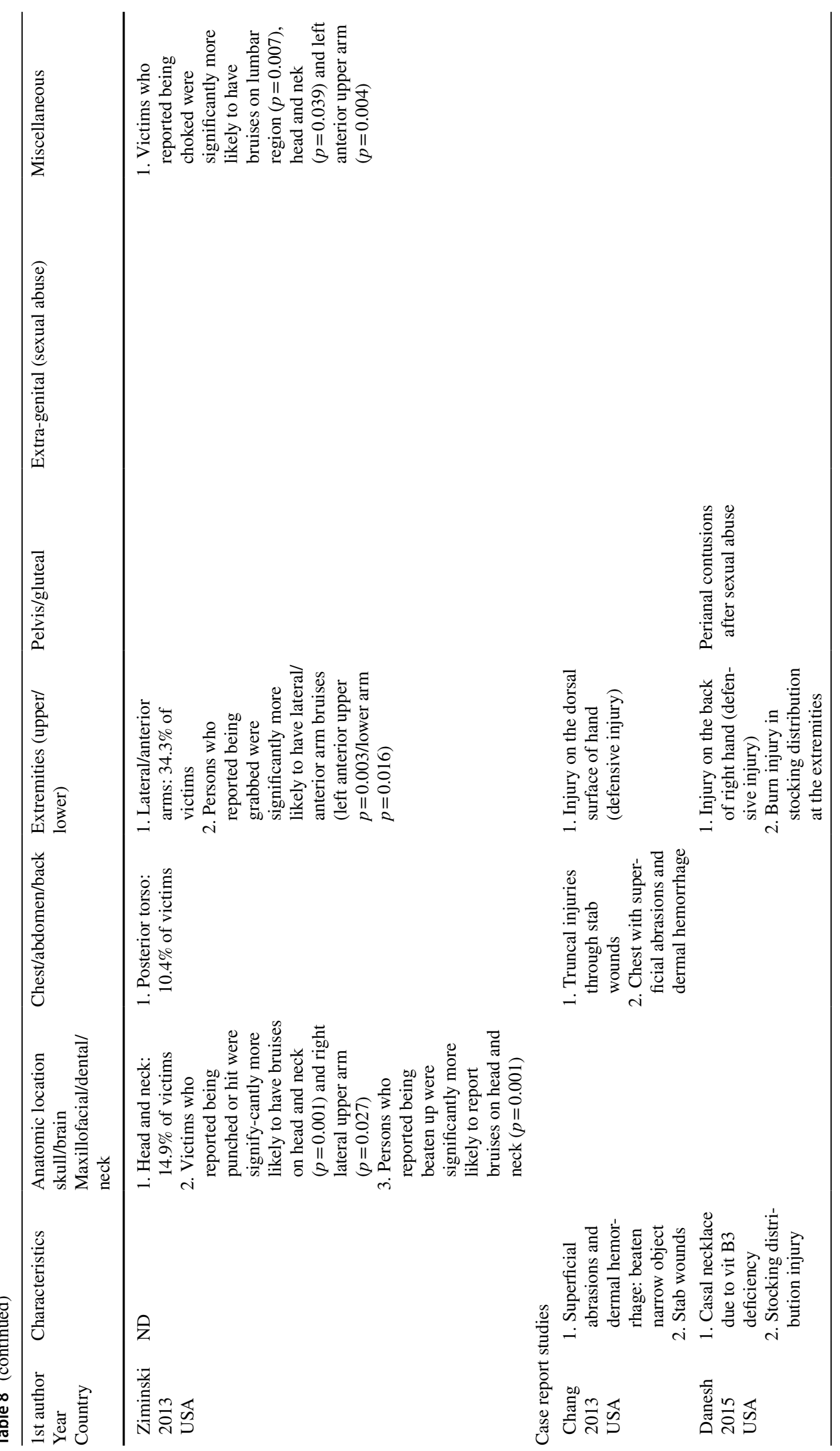




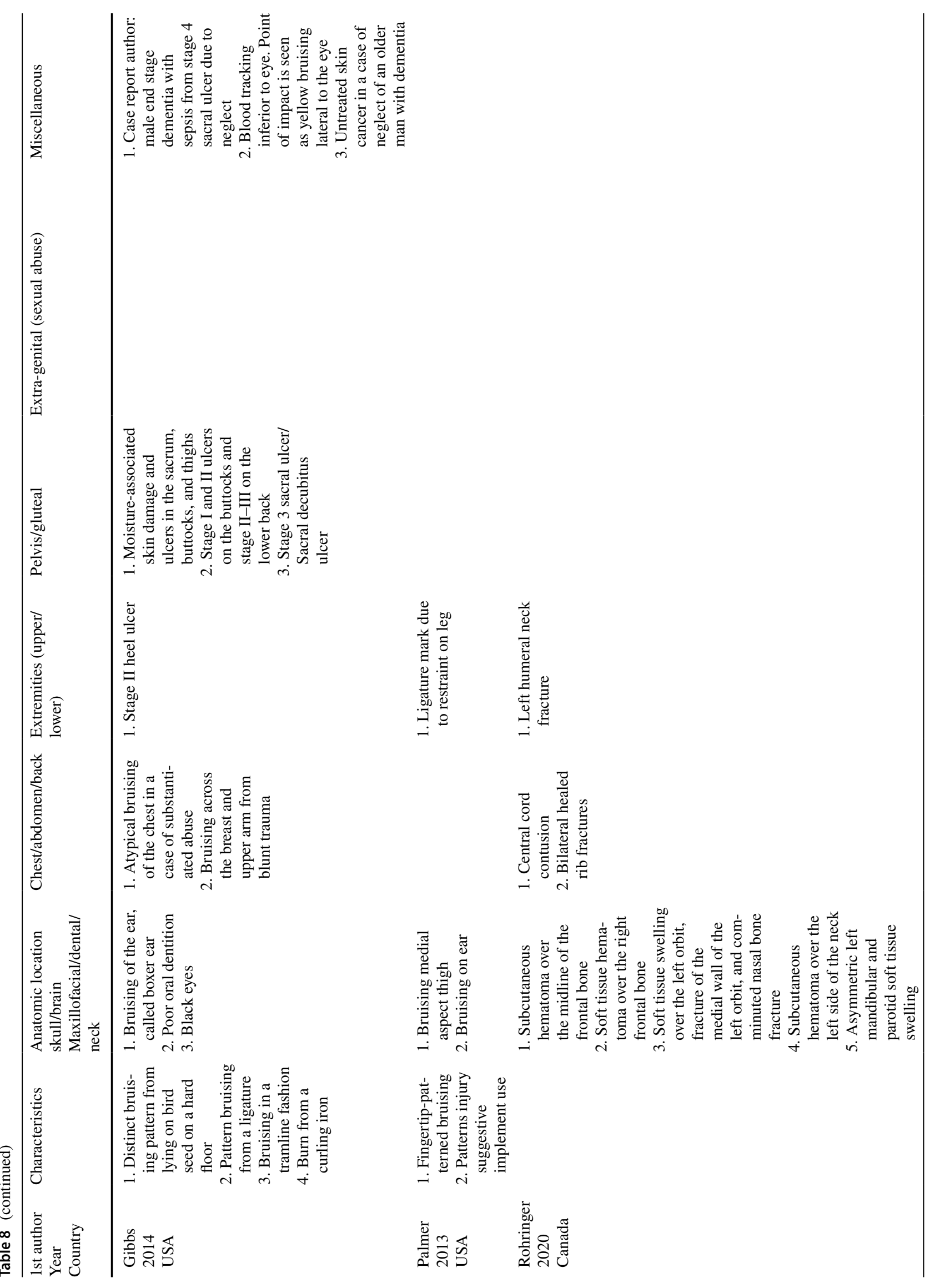




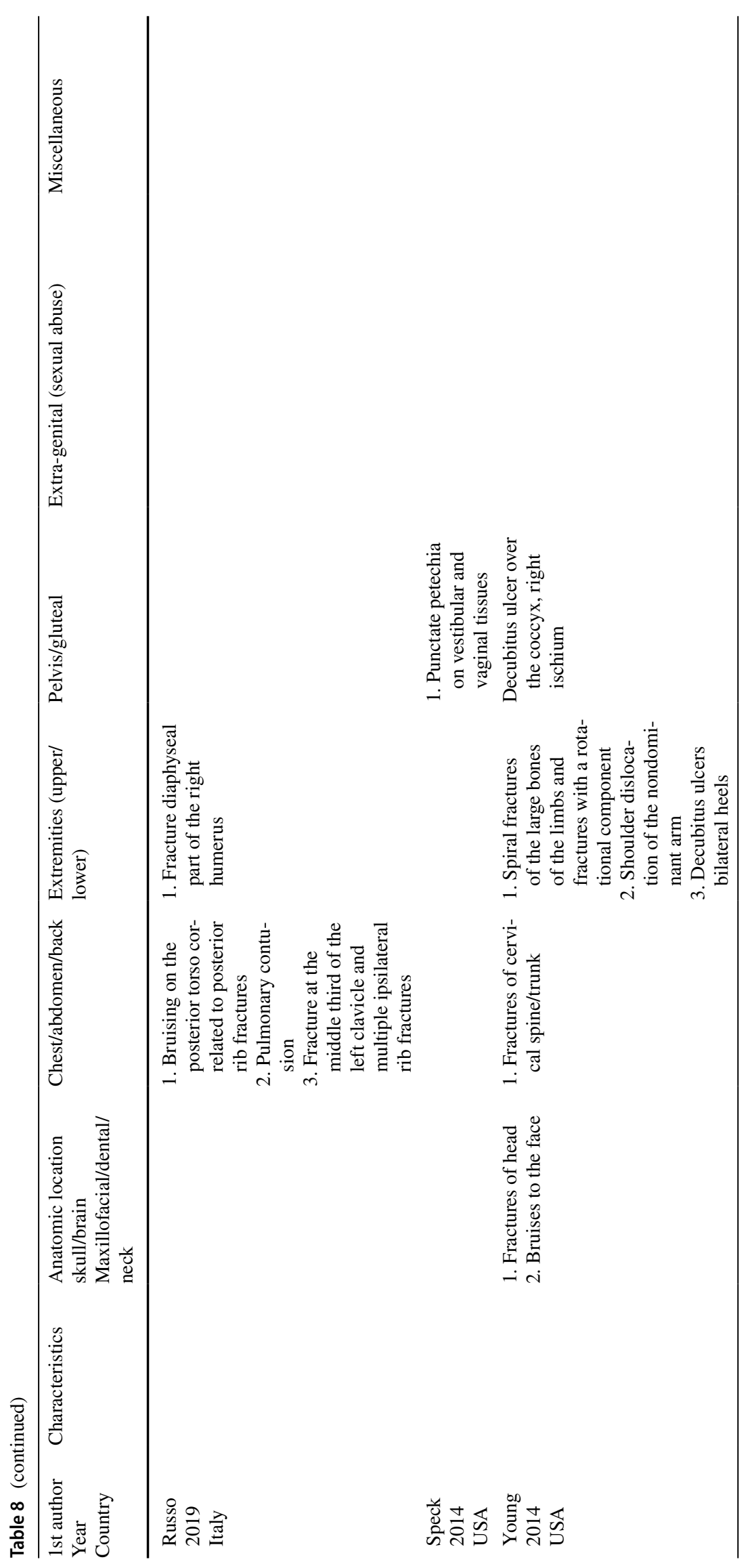




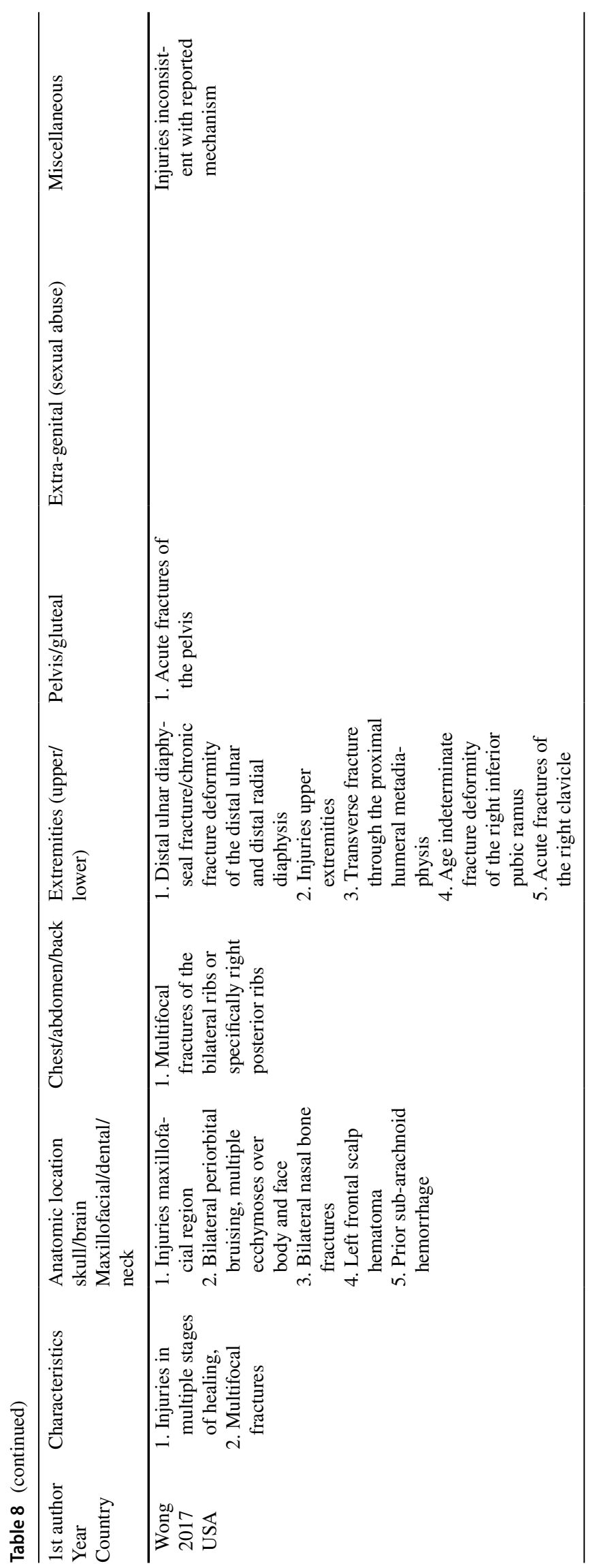




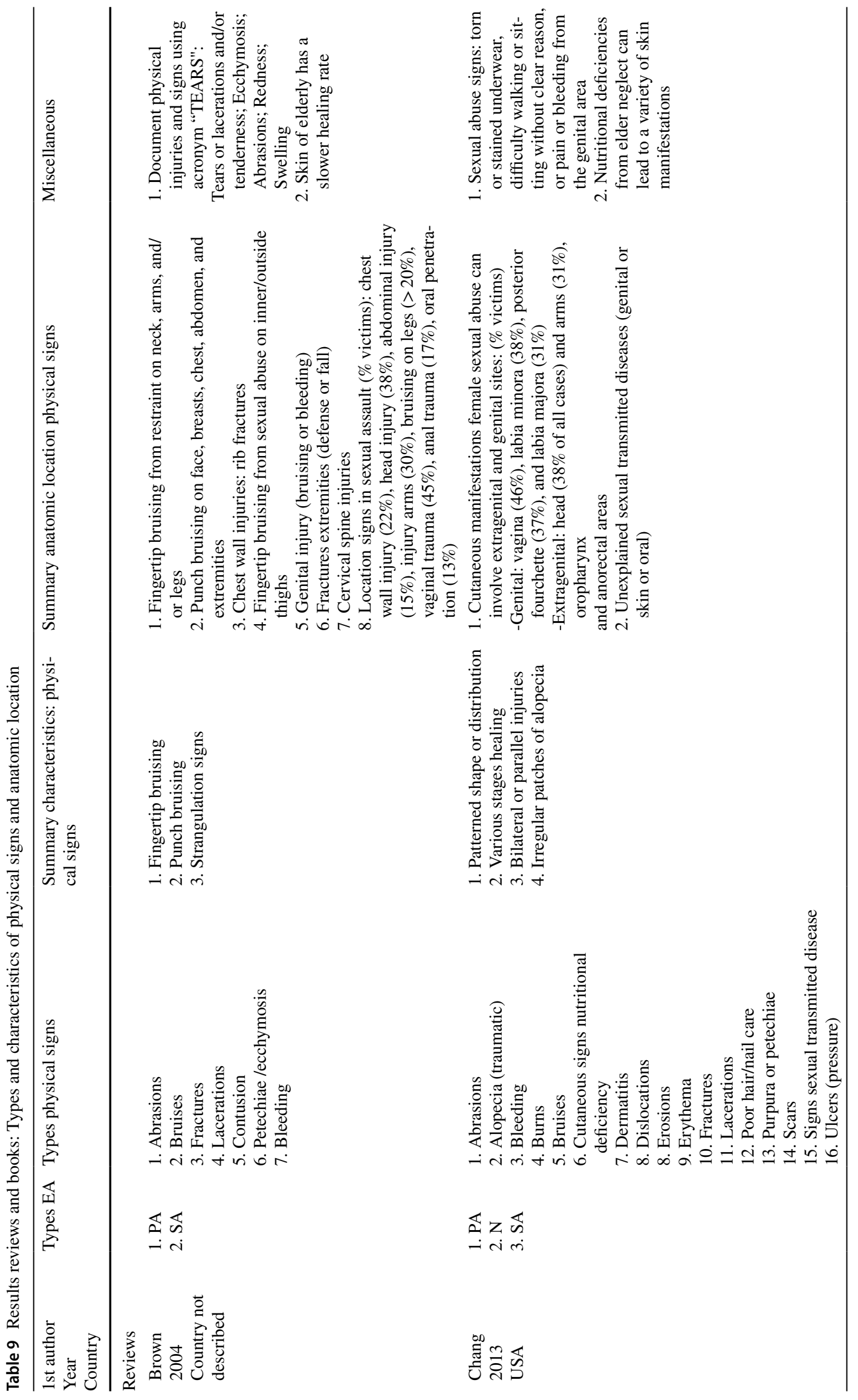




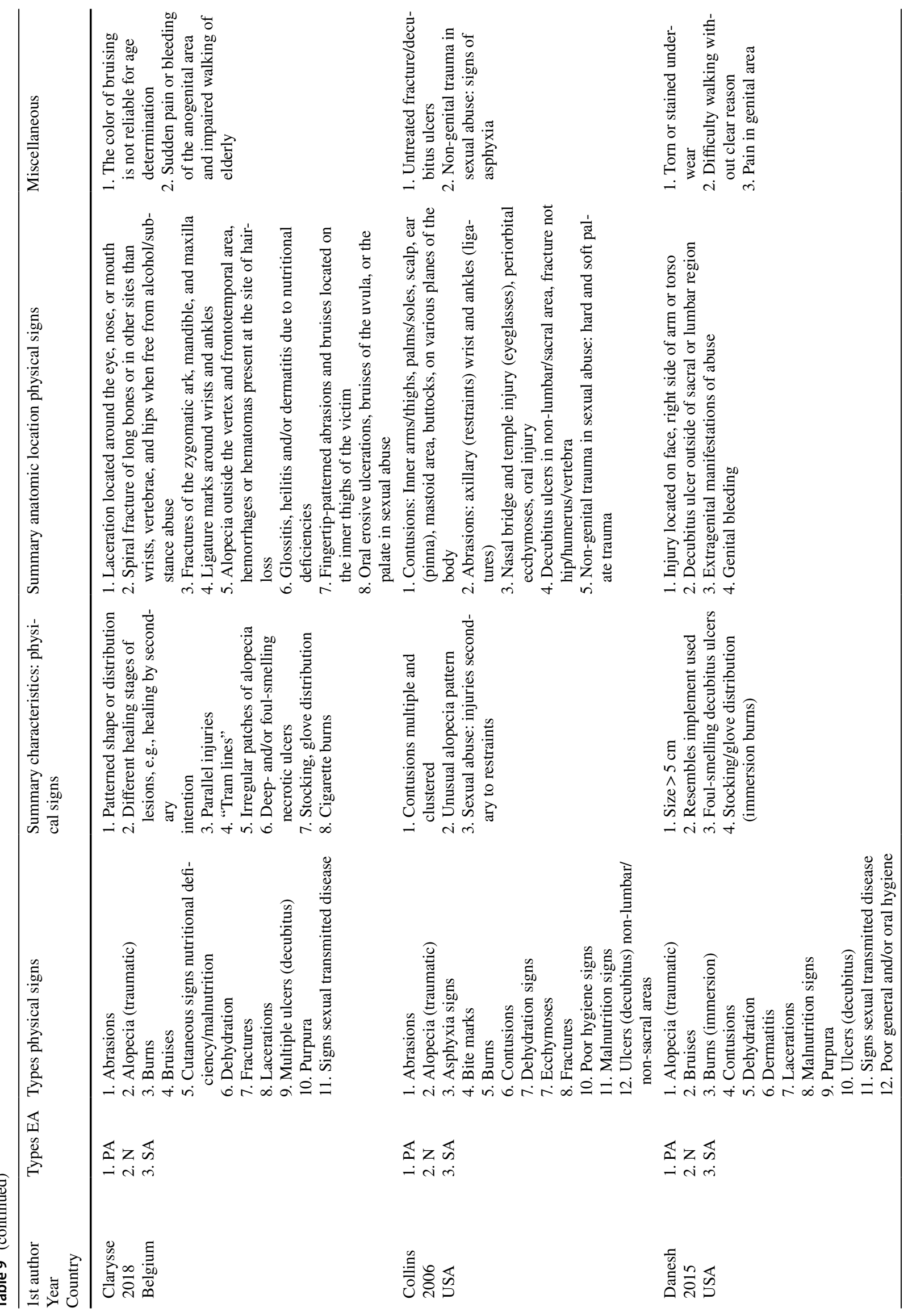




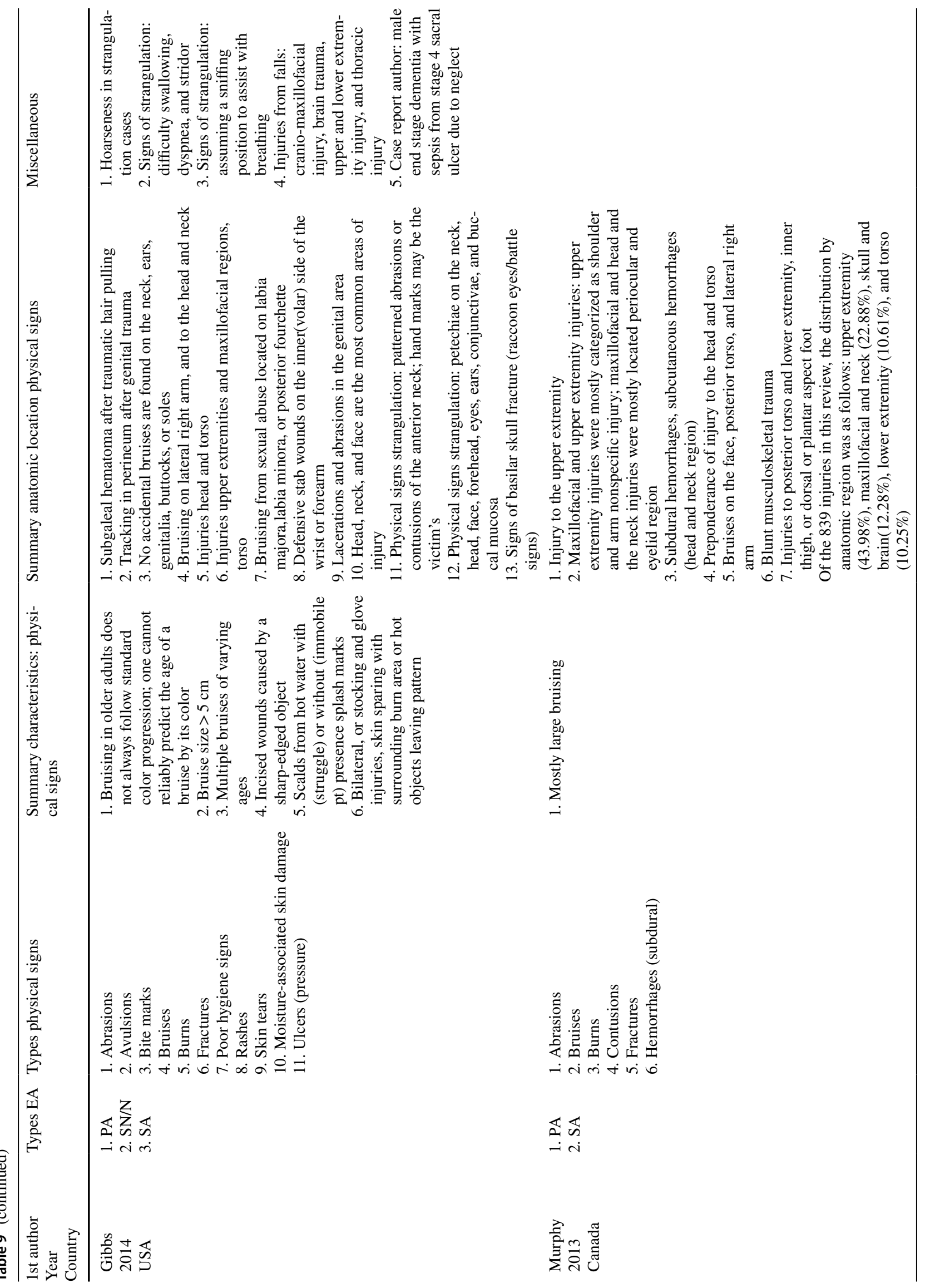




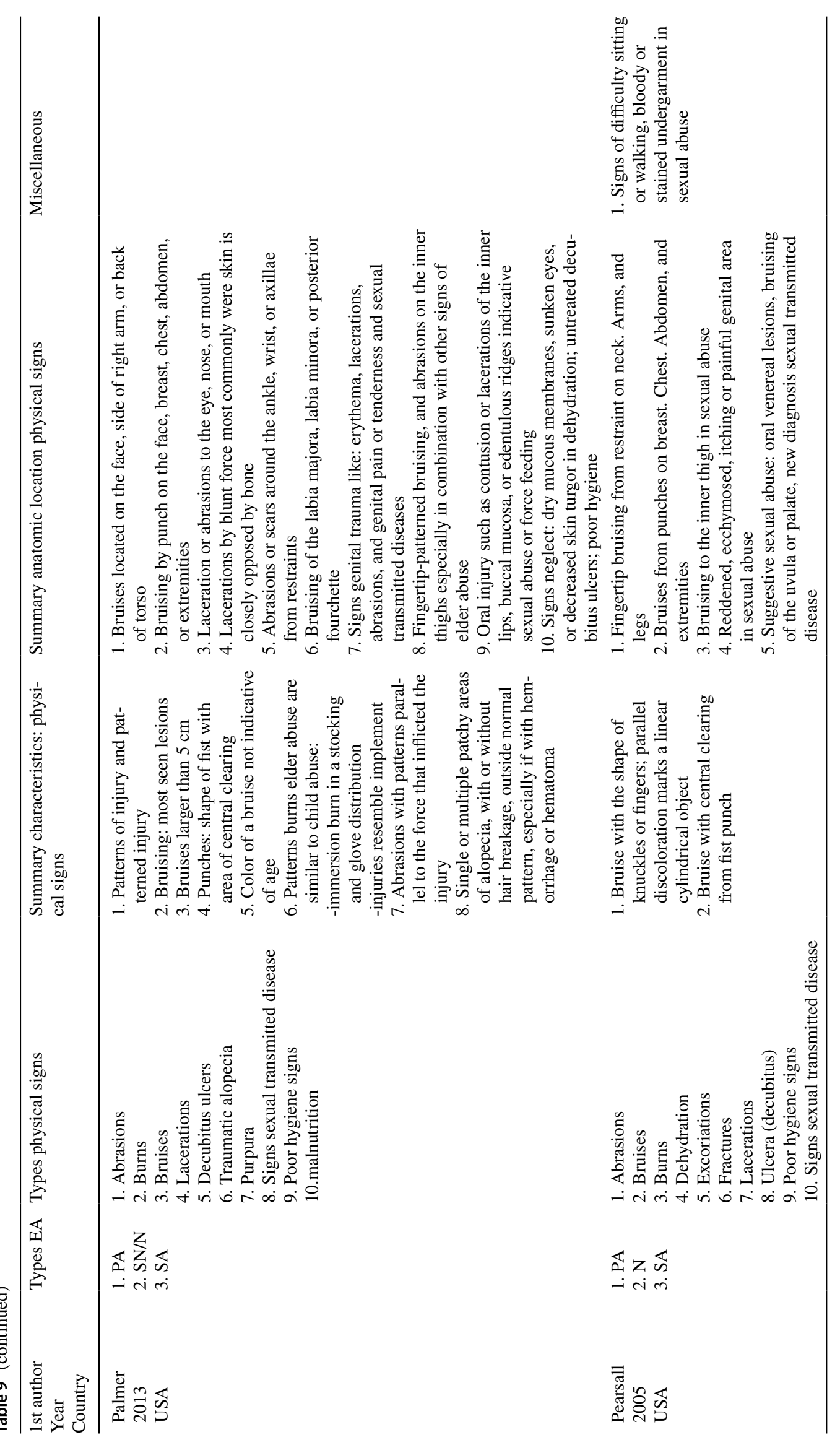




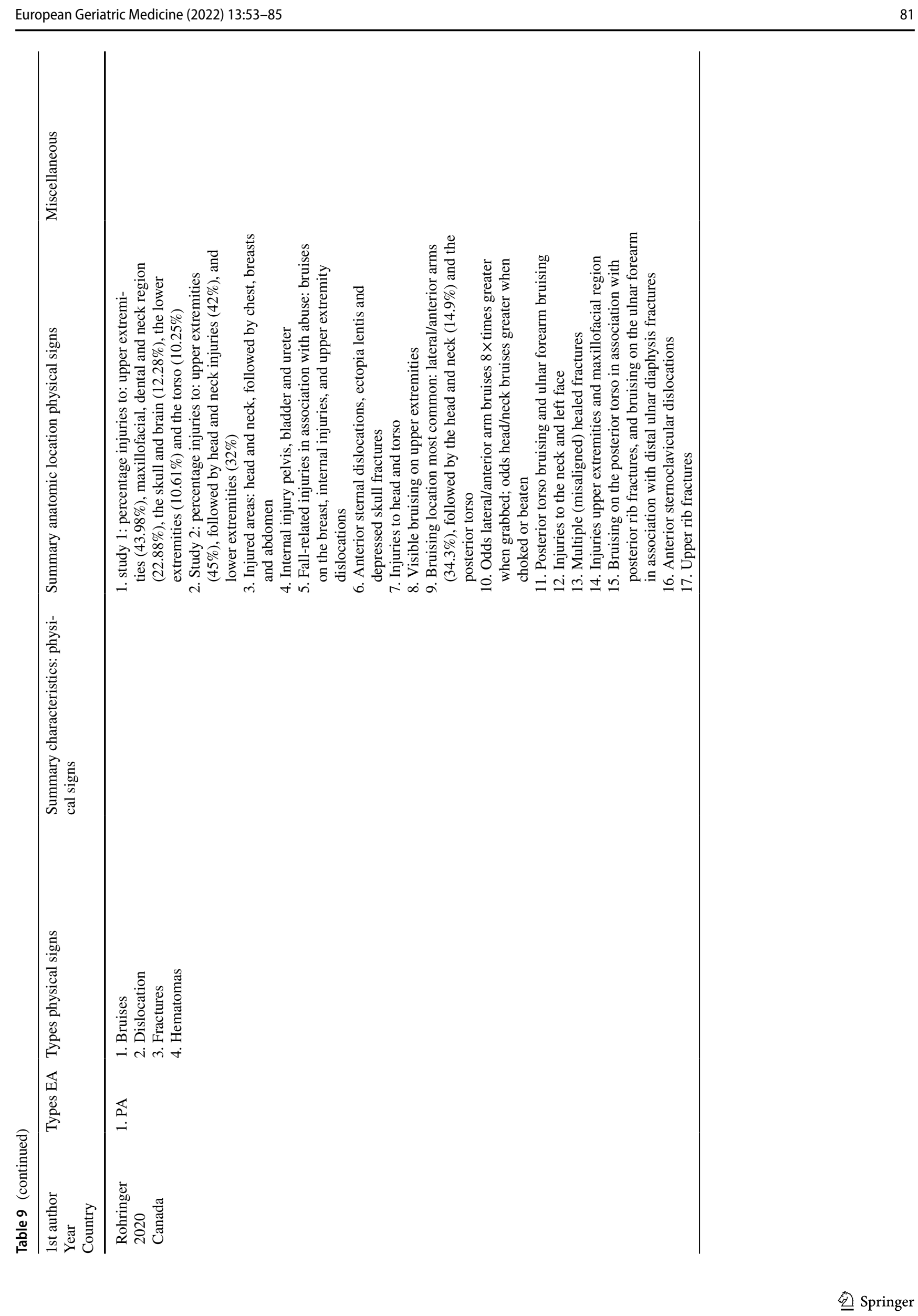




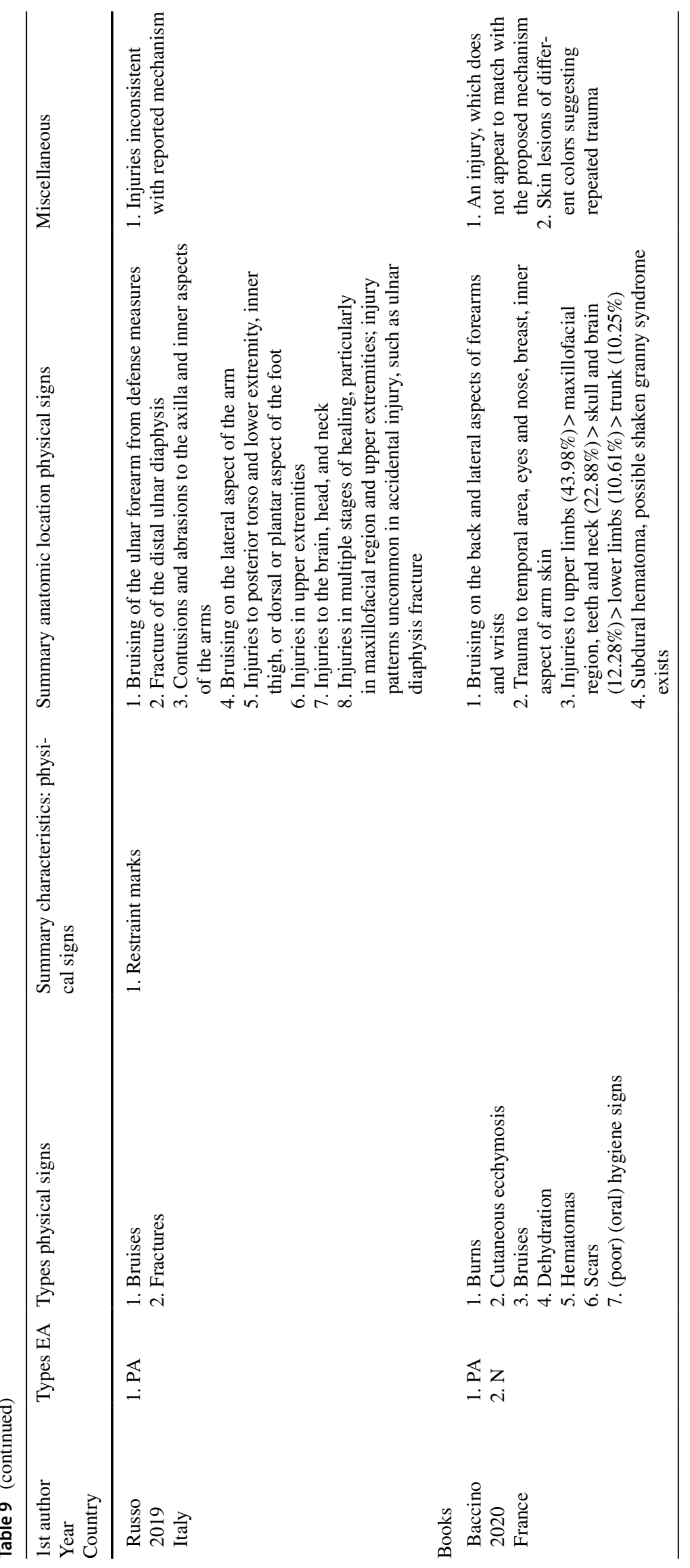




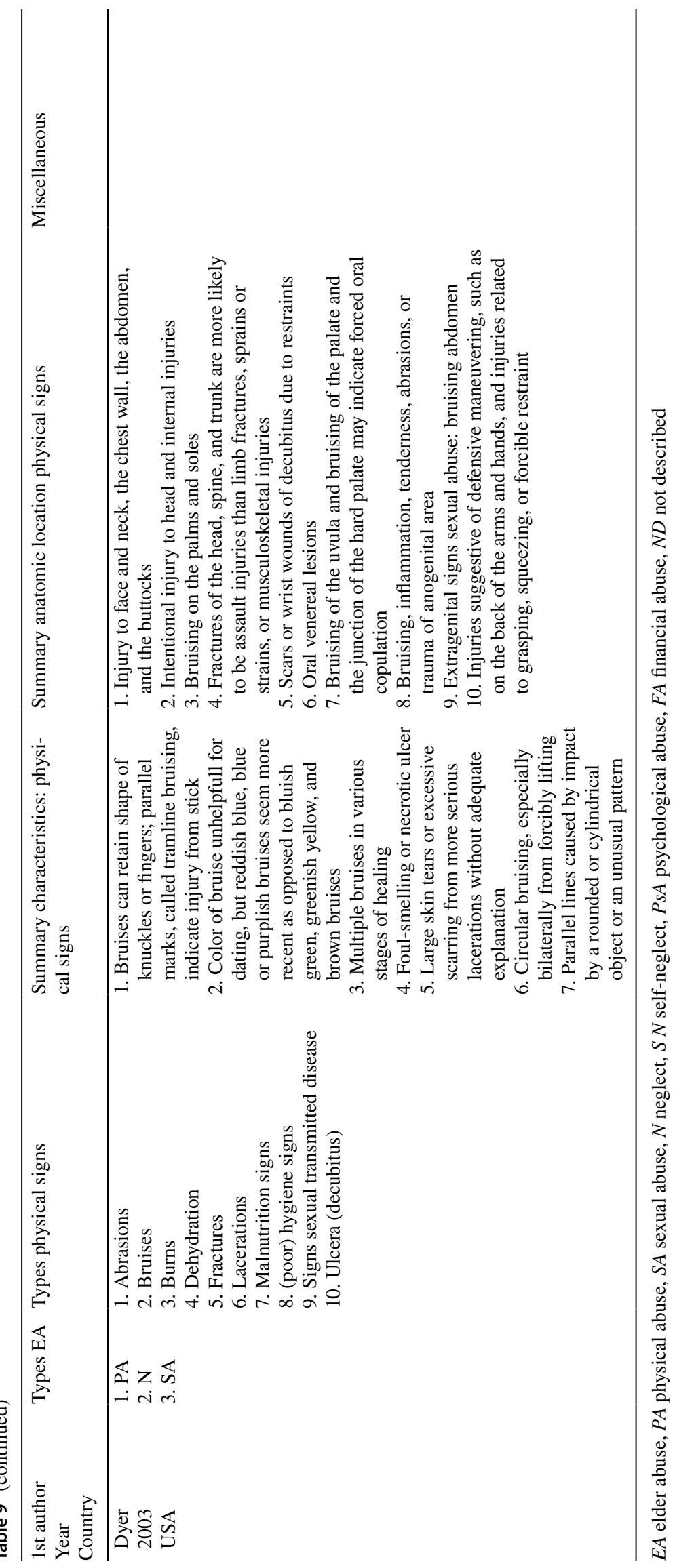


- There is a need for education on physical signs in elder abuse; furthermore, this topic should be included in clinical curricula at different levels (i.e., pre- and postqualification): not only in bachelor and master programs for professionals such as clinical geriatricians and emergency physicians, but also for nursing and other healthcare professionals.

Supplementary Information The online version contains supplementary material available at https://doi.org/10.1007/s41999-021-00550-z.

Author contributions Study concept and design: MVH, SB, LV; acquisition of subjects and/or data: MVH and SB; analysis and interpretation of data: MVH, SB and UR; preparation of manuscript: SB, LV, MVH and UR.

Funding Sponsor role, related paper presentations, preprints: no.

Availability of data and material In line with the nature of the systematic review, original research papers included in the article were provided with references.

Code availability Not applicable for the research design.

\section{Declarations}

Conflict of interest On behalf of all authors, the corresponding author states that there is no conflict of interest. The authors have no relevant financial or non-financial interests to disclose. The authors have no conflicts of interest to declare that are relevant to the content of this article. All authors certify that they have no affiliations with or involvement in any organization or entity with any financial interest or nonfinancial interest in the subject matter or materials discussed in this manuscript. The authors have no financial or proprietary interests in any material discussed in this article.

Ethics approval Not applicable.

Consent to participate: Not applicable.

Consent for publication: Not applicable.

Open Access This article is licensed under a Creative Commons Attribution 4.0 International License, which permits use, sharing, adaptation, distribution and reproduction in any medium or format, as long as you give appropriate credit to the original author(s) and the source, provide a link to the Creative Commons licence, and indicate if changes were made. The images or other third party material in this article are included in the article's Creative Commons licence, unless indicated otherwise in a credit line to the material. If material is not included in the article's Creative Commons licence and your intended use is not permitted by statutory regulation or exceeds the permitted use, you will need to obtain permission directly from the copyright holder. To view a copy of this licence, visit http://creativecommons.org/licenses/by/4.0/.

\section{References}

1. Lachs MS, Williams CS, O'Brien S, Pillemer KA, Charlson ME (1998) The mortality of elder mistreatment. JAMA 280(5):428432. https://doi.org/10.1001/jama.280.5.428

2. Dong X, Chen R, Chang ES, Simon M (2013) Elder abuse and psychological well-being: a systematic review and implications for research and policy-a mini review. Gerontology 59(2):132142. https://doi.org/10.1159/000341652

3. Dong X, Simon MA (2013) Elder abuse as a risk factor for hospitalization in older persons. JAMA Intern Med 173(10):911-917. https://doi.org/10.1001/jamainternmed.2013.238

4. Yon Y, Mikton CR, Gassoumis ZD, Wilber KH (2017) Elder abuse prevalence in community settings: a systematic review and meta-analysis. Lancet Glob Health 5(2):e147-e156. https://doi. org/10.1016/S2214-109X(17)30006-2

5. Lindenberg L, Jansen JHLJ, Bakker L, Witkamp B, Timmermans M (2018) Aard en omvang van ouderenmishandeling-Regioplan. https://www.regioplan.nl/project/aard-en-omvang-ouderenmis handeling/. Accessed 10 Feb 2021.

6. Garma CT (2017) Influence of health personnel's attitudes and knowledge in the detection and reporting of elder abuse: an exploratory systematic review. Psychosoc Interv 26(2):73-91. https://doi.org/10.1016/j.psi.2016.11.001

7. Corbi G, Grattagliano I, Sabbà C, Fiore G, Spina S, Ferrara N, Campobasso CP (2019) Elder abuse: perception and knowledge of the phenomenon by healthcare workers from two Italian hospitals. Intern Emerg Med 14(4):549-555. https://doi.org/10.1007/ s11739-019-02038-y

8. Lachs MS, Pillemer KA (2015) Elder abuse. N Engl J Med 373(20):1947-1956. https://doi.org/10.1056/NEJMra1404688

9. Moyer VA, U.S. Preventive Services Task Force (2013) Screening for intimate partner violence and abuse of elderly and vulnerable adults: US preventive services task force recommendation statement. Ann Intern Med 158(6):478-486. https://doi.org/10.7326/ 0003-4819-158-6-201303190-00588

10. Dong X, Simon MA (2013) Association between elder abuse and use of ED: findings from the Chicago Health and Aging Project. Am J Emerg Med 31(4):693-698. https://doi.org/10.1016/j.ajem. 2012.12.028

11. Murphy K, Waa S, Jaffer H, Sauter A, Chan A (2013) A literature review of findings in physical elder abuse. Can Assoc Radiol J 64(1):10-14. https://doi.org/10.1016/j.carj.2012.12.001

12. Palmer M, Brodell RT, Mostow EN (2013) Elder abuse: dermatologic clues and critical solutions. J Am Acad Dermatol 68(2):e3742. https://doi.org/10.1016/j.jaad.2011.03.016

13. Wiglesworth A, Austin R, Corona M, Schneider D, Liao S, Gibbs L, Mosqueda L (2009) Bruising as a marker of physical elder abuse. J Am Geriatr Soc 57(7):1191-1196. https://doi.org/10. 1111/j.1532-5415.2009.02330.x

14. Higgins JPT, Thomas J, Chandler C, Cumpston M, Li T, Page MJ, Welch VA (2019) Cochrane handbook for systematic reviews of interventions, 2nd edn. Wiley

15. Moher D, Liberati A, Tetzlaff J, Altman DG, PRISMA Group (2010) Preferred reporting items for systematic reviews and metaanalyses: the PRISMA statement. Int J Surg 8(5):336-341. https:// doi.org/10.1016/j.ijsu.2010.02.007

16. Baker PR, Francis DP, Hairi NN, Othman S, Choo WY (2016) Interventions for preventing abuse in the elderly. Cochrane Database Syst Rev. https://doi.org/10.1002/14651858.CD010321.pub2

17. Dutch Society Clinical geriatrics (2018) Evidence based practice guideline on elder abuse in the medical specialist setting. In: Richtlijnendatabase Federatie Medisch Specialisten. https://richtlijne ndatabase.nl/richtlijn/vermoeden_van_ouderenmishandeling_om/ 
startpagina_-_vermoeden_ouderenmishandeling.html. Accessed 18 Apr 2021.

18. Kmet L, Lee R, Cook L (2004) Standard Quality Assessment Criteria for evaluating primary research papers from a variety of fields. In: Institute of Health Economics Alberta Canada. https:// www.ihe.ca/publications/standard-quality-assessment-criteriafor-evaluating-primary-research-papers-from-a-variety-of-fields. Accessed 10 Apr 2021.

19. Hong QN, Pluye P, Fàbregues S, Bartlett G, Boardman F, Cargo M, Dagenais P, Gagnon MP, Griffiths F, Nicolau B, O'Cathain A, Rousseau MC, Vedel I (2019) Improving the content validity of the mixed methods appraisal tool: a modified e-Delphi study. J Clin Epidemiol 111:49-59.e1. https://doi.org/10.1016/j.jclinepi. 2019.03.008

20. Rosen T, Reisig C, LoFaso VM, Bloemen EM, Clark S, McCarthy TJ, Mtui EP, Flomenbaum NE, Lachs MS (2017) Describing visible acute injuries: development of a comprehensive taxonomy for research and practice. Inj Prev 23(5):340-345. https://doi.org/10. 1136/injuryprev-2016-042131

21. Abath Mde B, Leal MC, Melo Filho DA, Marques AP (2010) Physical abuse of older people reported at the Institute of Forensic Medicine in Recife, Pernambuco State. Brazil Cad Saude Publica 26(9):1797-1806. https://doi.org/10.1590/s0102-311x201000 0900013

22. Burgess AW, Hanrahan NP, Baker T (2005) Forensic markers in elder female sexual abuse cases. Clin Geriatr Med 21(2):399-412. https://doi.org/10.1016/j.cger.2004.10.005

23. Cham GW, Seow E (2000) The pattern of elderly abuse presenting to an emergency department. Singap Med J 41(12):571-574

24. Kavak RP, Ozdemir M (2019) Radiological appearance of physical elder abuse. Euro Geriatr Med 10(6):871-878. https://doi.org/ 10.1007/s41999-019-00246-5

25. Rosen T, Bloemen EM, LoFaso VM, Clark S, Flomenbaum NE, Lachs MS (2016) Emergency department presentations for injuries in older adults independently known to be victims of elder abuse. J Emerg Med 50(3):518-526. https://doi.org/10.1016/j. jemermed.2015.10.037

26. Rosen T, LoFaso VM, Bloemen EM, Clark S, McCarthy TJ, Reisig C, Gogia K, Elman A, Markarian A, Flomenbaum NE, Sharma R, Lachs MS (2020) Identifying injury patterns associated with physical elder abuse: analysis of legally adjudicated cases. Ann Emerg Med 76(3):266-276. https://doi.org/10.1016/j.annem ergmed.2020.03.020

27. Ziminski CE, Wiglesworth A, Austin R, Phillips LR, Mosqueda L (2013) Injury patterns and causal mechanisms of bruising in physical elder abuse. J Forensic Nurs 9(2):84-91. https://doi.org/ 10.1097/JFN.0b013e31827d51d0 (Quiz E1-2)

28. Speck PM, Hartig MT, Likes W, Bowdre T, Carney AY, Ekroos RA, Haugen R, Crum J, Faugno DK (2014) Case series of sexual assault in older persons. Clin Geriatr Med 30(4):779-806. https:// doi.org/10.1016/j.cger.2014.08.007

29. Young LM (2014) Elder physical abuse. Clin Geriatr Med 30(4):761-768. https://doi.org/10.1016/j.cger.2014.08.005

30. Wong NZ, Rosen T, Sanchez AM, Bloemen EM, Mennitt KW, Hentel K, Nicola R, Murphy KJ, LoFaso VM, Flomenbaum NE,
Lachs MS (2017) Imaging findings in elder abuse: a role for radiologists in detection. Can Assoc Radiol J 68(1):16-20. https://doi. org/10.1016/j.carj.2016.06.001

31. Brown K, Streubert GE, Burgess AW (2004) Effectively detect and manage elder abuse. Nurse Pract 29(8):22-27. https://doi.org/10. 1097/00006205-200408000-00004 (Quiz 32-3)

32. Clarysse K, Kivlahan C, Beyer I, Gutermuth J (2018) Signs of physical abuse and neglect in the mature patient. Clin Dermatol 36(2):264-270. https://doi.org/10.1016/j.clindermatol.2017.10. 018

33. Collins KA (2006) Elder maltreatment: a review. Arch Pathol Lab Med 130(9):1290-1296. https://doi.org/10.5858/ 2006-130-1290-EMAR

34. Pearsall C (2005) Forensic biomarkers of elder abuse: what clinicians need to know. J Forensic Nurs 1(4):182-186. https://doi.org/ 10.1111/j.1939-3938.2005.tb00043.x

35. Chang ALS, Wong JW, Endo JO, Norman RA (2013) Geriatric dermatology: Part II. Risk factors and cutaneous signs of elder mistreatment for the dermatologist. J Am Acad Dermatol 68(4):533.e1-533.e10. https://doi.org/10.1016/j.jaad.2013.01.001

36. Danesh MJ, Chang AL (2015) The role of the dermatologist in detecting elder abuse and neglect. J Am Acad Dermatol 73(2):285-293. https://doi.org/10.1016/j.jaad.2015.04.006

37. Gibbs LM (2014) Understanding the medical markers of elder abuse and neglect: physical examination findings. Clin Geriatr Med 30(4):687-712. https://doi.org/10.1016/j.cger.2014.08.002 (Epub 2014 Oct 24. PMID: 25439636.38)

38. Rohringer TJ, Rosen TE, Lee MR, Sagar P, Murphy KJ (2020) Can diagnostic imaging help improve elder abuse detection? Br J Radiol 93(1110):20190632. https://doi.org/10.1259/bjr.20190632

39. Russo A, Reginelli A, Pignatiello M, Cioce F, Mazzei G, Fabozzi O, Parlato V, Cappabianca S, Giovine S (2019) Imaging of violence against the elderly and the women. Semin Ultrasound CT MR 40(1):18-24. https://doi.org/10.1053/j.sult.2018.10.004

40. Baccino E, Lossois M (2020) Imaging and elderly abuses. Radiology in forensic medicine. Springer, pp 145-155. https://doi.org/ 10.1007/978-3-319-96737-0_13

41. Dyer CB, Connolly MT, McFeeley P (2003) The clinical and medical forensics of elder abuse and neglect. In: Bonnie RJ, Wallace RB (eds) Elder mistreatment: abuse, neglect, and exploitation in an aging America. National Academies Press, Washington, p 12

42. Feltner C, Wallace I, Berkman N, Kistler CE, Middleton JC, Barclay C, Higginbotham L, Green JT, Jonas DE (2018) Screening for intimate partner violence, elder abuse, and abuse of vulnerable adults: evidence report and systematic review for the US Preventive Services Task Force. JAMA 320(16):1688-1701. https://doi. org/10.1001/jama.2018.13212

43. Gallione C, Dal Molin A, Cristina FVB, Ferns H, Mattioli M, Suardi B (2017) Screening tools for identification of elder abuse: a systematic review. J Clin Nurs 26(15-16):2154-2176. https:// doi.org/10.1111/jocn.13721

Publisher's Note Springer Nature remains neutral with regard to jurisdictional claims in published maps and institutional affiliations. 